\title{
HEINONLINE
}

Citation: 61 Vand. L. Rev. 12008

Content downloaded/printed from HeinOnline (http://heinonline.org)

Tue May 29 11:59:10 2012

-- Your use of this HeinOnline PDF indicates your acceptance of HeinOnline's Terms and Conditions of the license agreement available at http://heinonline.org/HOL/License

-- The search text of this PDF is generated from uncorrected OCR text.

-- To obtain permission to use this article beyond the scope of your HeinOnline license, please use:

https://www.copyright.com/ccc/basicSearch.do?

\&operation $=$ go\&search Type $=0$

\&lastSearch $=$ simple\&all $=$ on\&titleOrStdNo $=0042-2533$

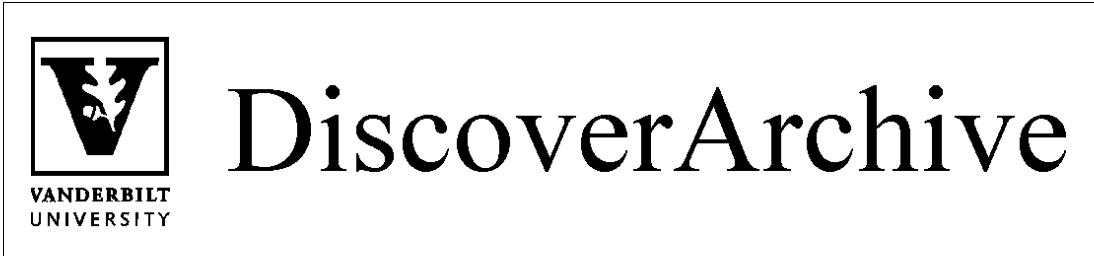

Retrieved from DiscoverArchive,

Vanderbilt University's Institutional Repository

This work was originally published in

61 Vand. L. Rev. 12008 


\title{
VANDERBILT LAW REVIEW
}

\section{Chief Judges: The Limits of Attitudinal Theory and Possible Paradox of Managerial Judging}

\author{
Tracey E. George ${ }^{\star} \&$ Albert H. Yoon ${ }^{* *}$
}

I. INCENTIVES ON THE U.S. COURTS OF APPEALS ...................... 9

A. The Attitudinal Model ............................................ 10

1. The Role of Policy Preferences in

Votes on the Merits ........................................ 11

2. The Role of Policy Preferences in

Non-Merits Decisions ..................................... 16

B. $\quad$ The Managerial Judging Model ............................... 19

II. LEADERSHIP ON THE LOWER FEDERAL COURTS ...................... 20

A. The Creation and Selection of Chief Judges .............. 23

B. The Real and Potential Power of Chief Judges ......... 28

1. The Chief Judge on a Panel ........................... 28

2. Formal Authority ......................................... 29

3. Informal Powers ........................................... 33

* Professor of Law, Vanderbilt University.

* Professor of Law, Northwestern University. We presented this paper at the 2006 Law \& Society Association Annual Meeting, the Second Annual Conference on Empirical Legal Studies, and at a Marquette University faculty workshop. We thank Jason Czarnezki, Shari Diamond, Brian Fitzpatrick, John Goldberg, Chris Guthrie, Stefanie Lindquist, Richard McAdams, Richard Nagareda, Erin O'Hara, Mary Rose, Jeff Segal, and Suzanna Sherry for helpful comments. Jessica Friedman, Linda Leibfarth, and Donya Mir provided excellent research assistance. We owe a large debt to Vanderbilt Law School reference librarian Janet Hirt, who assisted us in tracking down elusive data on many of the judges in this study, and to the federal court staff members who assisted us. 


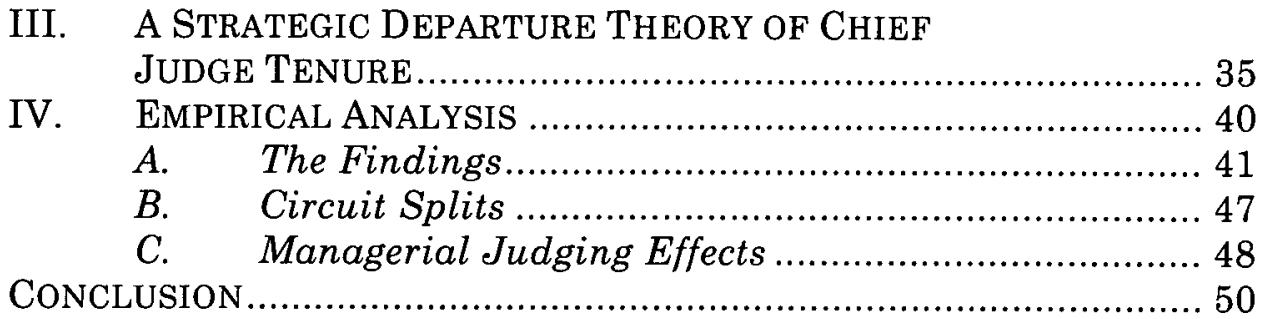

Grutter $v$. Bollinger is familiar to American lawyers, academics, and law students as the Supreme Court decision allowing the consideration of race in law school admissions. ${ }^{1}$ Grutter's procedural history is nearly as noteworthy as its substantive holding. The University of Michigan Law School, after losing in federal district court, $^{2}$ appealed to the U.S. Court of Appeals for the Sixth Circuit. ${ }^{3}$ Three Democratic appointees were assigned to the panel: Judges Karen Nelson Moore and Martha Craig Daughtrey, who had heard an earlier interlocutory appeal, and Chief Judge Boyce Martin, who replaced the designated district judge from the earlier panel. ${ }^{4}$ The white applicant requested that the entire court, rather than a panel, hear the case. ${ }^{5}$ The Sixth Circuit granted the en banc petition. ${ }^{6}$ A

1. 539 U.S. 306 (2003) (upholding the University of Michigan Law School's method for considering race and ethnicity in its admissions policy, but striking down, in the related lawsuit, Gratz v. Bollinger, 539 U.S. 244 (2003), the specific affirmative action methodology used by the undergraduate admissions program).

2. Grutter v. Bollinger, 137 F. Supp. 2d 821, 872 (E.D. Mich. 2001) (holding, in an opinion by Judge Bernard A. Friedman, that the University of Michigan Law School's consideration of race in admissions violated the Equal Protection Clause of the 14th Amendment and Title VI of the Civil Rights Act).

3. The appeal was filed on April 2, 2001. Id., appeal docketed, No. 01-1447 (6th Cir. Apr. 2, 2001) [hereinafter Grutter Docket Sheet]. The Grutter Docket Sheet is publicly available. It does not reflect, however, certain internal activities of the court, such as circulation of petitions for votes, specific votes on those petitions, or the identity of judges other than the judge (or judges) who sign an order. The Sixth Circuit maintains a private docket that includes such additional information. This private docket sheet usually is not available to the public, but its content was described in a concurring opinion in the case. See Grutter v. Bollinger, 288 F.3d 732, 752, 754 (6th Cir. 2002) (en banc) (Moore, J., concurring) (describing the "private docket" in the case).

4. While the Grutter Docket Sheet does not reflect the composition of the new panel, it does disclose decisions by the panel regarding minor matters that arose between the law school's filing of the notice of appeal and oral argument. See, e.g., Grutter Docket Sheet, supra note 3, April 5, 2001 entry (noting the panel decision in Grutter v. Bollinger, 247 F.3d 631, 633 (6th Cir. 2001), a ruling by Martin, Daughtrey, and Moore on April 5, 2001, which granted the law school's request for a stay, pending appeal, of the district court's order enjoining the consideration of race in admissions).

5. See Grutter Docket Sheet, supra note 3, May 14, 2001 entry (showing petition for en banc hearing prior to submission of briefs).

6. Gratz v. Bollinger, 277 F.3d 803, 803 (6th Cir. 2001) (en banc) (granting en banc hearing by order dated October 19, 2001). 
closely divided en banc court reversed the district court in an opinion authored by Martin. ${ }^{7}$

Normally, that is all we would know about the process by which the Sixth Circuit decided the case. But something highly unusual happened. Judge Danny Boggs included with his dissenting opinion a five-page procedural appendix detailing intracourt machinations and accusing the Chief Judge of manipulating procedures to affect the outcome. ${ }^{8}$ Boggs alleged that Martin violated circuit rules by assigning himself, rather than a randomly selected judge, to the three-judge panel. ${ }^{9}$ This assertion alone does not seem very significant-the case was decided, after all, by the en banc court. Boggs's more pointed accusation was that Martin engineered the en banc voting process to ensure a court balanced in favor of the law school. When the white student petitioned for an en banc hearing, eleven active judges sat on the Sixth Circuit; two of those judges had expressed their intent to take senior status. ${ }^{10}$ Martin circulated the petition after both judges had taken senior status, making them ineligible to participate. ${ }^{11}$ Judge Alice Batchelder responded by

7. Grutter, 288 F.3d at 735 (upholding the law school's admissions policy by a five-to-four vote with Judges Daughtrey, Moore, Cole, and Clay joining Martin's opinion and Judges Boggs, Siler, Batchelder, and Gilman dissenting).

8. See id. at 810-14 (Boggs, J., dissenting) (discussing concerns relating to the alleged violations of internal procedures in granting this en banc review); id. at 773 (Clay, J., concurring) (noting Judge Boggs's divulgence of internal information).

9. See id. at 810-14 (Boggs, J., dissenting) (alleging Martin violated then-Sixth Circuit Internal Operating Procedure Rule 34(b)(2), which provided that subsequent appeals would be returned to the original panel for a determination of "whether the second appeal should be submitted to it for decision, or assigned to a panel at random," and that when a district court judge sat on the original panel, the remaining two circuit judges were to decide whether to recall that district judge or to select another circuit judge at random).

10. The petition was filed with the court on May 14, 2001. Grutter Docket Sheet, supra note 3, May 14, 2001 entry. Judge Alan Norris, a Ronald Reagan appointee, took senior status on July 1, 2001, and Judge Richard Suhrheinrich, a George H.W. Bush appointee, took senior status on August 15, 2001. See Federal Judicial Center, Biographical Directory of Federal Judges, http://www.fjc.gov/public/home.nsf/hisj (for Judge Norris, search "Norris, Alan," then follow link; for Judge Suhrheinrich, search "Suhrheinrich, Richard," then follow link) (last visited Dec. 26, 2007).

11. The Sixth Circuit's practice at that time was to allow senior judges to sit on the en banc panel if they were "in regular active service at the time a poll was requested on the petition" for an en banc hearing. Grutter, 288 F.3d at 812 n.44 (Boggs, J., dissenting) (quoting then-Sixth Circuit Internal Operating Procedures rule 35(a)); see also Popovich v. Cuyahoga County Court of Common Pleas, 276 F.3d 808, 829-30 (6th Cir. 2002) (en banc) (describing the Sixth Circuit's rule regarding composition of the en banc court). Both Norris and Suhrheinrich were active at the time the appellee filed her petition, but both apparently had taken senior status by the time a poll was taken. Neither Norris nor Suhrheinrich participated in the en banc petition vote, as reflected in their absence from the list of judges voting on the petition. Gratz, 277 F.3d 803 (ordering, on October 19,2001, that Grutter v. Bollinger, along with the undergraduate admissions case Gratz v. Bollinger, be heard initially en banc, and that oral argument in front of 
writing an internal memo to her colleagues contending that Martin delayed the vote on the white student's request for a hearing en banc until judges opposed to affirmative action took senior status. ${ }^{12}$ Boggs's dissent made public those accusations, a fact that one colleague called "shameful,"13 and another "embarrassing and incomprehensible."14

Accusations like those made in Grutter are consistent with the attitudinal theory of judicial decisionmaking. Attitudinal theory proffers that judges are political actors who make decisions that will maximize their policy preferences. ${ }^{15}$ Developed primarily by political scientists, this approach has gained increasing currency in legal scholarship. ${ }^{16}$ If the theory is an accurate account of any judicial action on the courts of appeals, we would expect, at a minimum, to see evidence in the behavior of chief judges, who have more opportunities than other circuit judges to achieve policy goals. Chief judges may behave attitudinally in exercising their formal powers as well as their informal authority and influence.

the three-judge panel, scheduled for October 23, 2001, be cancelled). The Sixth Circuit later changed its en banc participation rule to allow only judges in active service at the time of the en banc hearing to sit on the en banc court, avoiding the appearance of conflict with the statutory authorization for en banc hearings. Id. (noting that the rule was changed to comply with 28 U.S.C. $\S 46(c)$ as amended in 1996).

12. See Grutter, 288 F.3d at 815 (Batchelder, J., dissenting) (concurring in Judge Boggs's dissenting opinion setting forth her accusation); Charles Lane, Judges Spar Over Affirmative Action, WASH. POST, June 7, 2003, at A4 (noting the accusations set forth in the memorandum).

13. Grutter, 288 F.3d at 752.53 (Moore, J., concurring) (accusing Judge Boggs and Judge Batchelder, who concurred in Boggs's procedural appendix, of doing "a grave harm not only to themselves, but to this court and even to the Nation as a whole" by "publiciz[ing] disagreements over the internal workings of the court," and calling their conduct "nothing short of shameful")

14. Id. at 772 (Clay, J., concurring) (questioning Boggs's stated reasons for criticizing the Chief Judge's procedural decisions, and arguing that Boggs was motivated by disagreement with the majority rather than by any legitimate complaint); see also Lane, supra note 12 (reporting that Chief Judge "Martin accused Batchelder and other conservatives of trying to delegitimize the 6th Circuit's ruling to increase the chances it [would] be overturned").

15. For the best explication and defense of the attitudinal model, see generally JEFFREY A. Segal \& Harold J. SPaETh, The Supreme CoURT and THE ATtitudinal Model (1993); JefFrey A. SEgal \& HaRold J. SPAETh, The Supreme Court and the ATTITUdinal Model REvisited (2002) [hereinafter SEGal \& SPAETH, ATTITUdinal MOdEL REvisiTED].

16. For a discussion of the development of this model in political science, see Tracey E. George, Developing a Positive Theory of Decisionmaking on U.S. Courts of Appeals, 58 OHIO ST. L.J. 1635, 1646-66 (1998). For a discussion of its relevance to legal scholars, see, for example, Thomas W. Merrill, The Making of the Second Rehnquist Court: A Preliminary Analysis, 47 ST. LOUIS U. L.J. 569 (2003), which draws on the work of political scientists who study the Supreme Court but writes from the perspective of a legal scholar who believes the law matters, and Gregory C. Sisk, Michael Heise \& Andrew P. Morriss, Charting the Influences on the Judicial Mind: An Empirical Study of Judicial Reasoning, 73 N.Y.U. L. REV. 1377 (1998), which tests a multivariate model of judicial decisions on the constitutionality of the Federal Sentencing Guidelines. 
The attitudinal explanation for the events in Grutter is quite simple and intuitive: Chief Judge Martin, a Carter appointee, supported affirmative action and manipulated procedure to ensure the case would be decided by judges who shared his view. ${ }^{17}$ That is, he substituted himself for the designated district judge who had heard the interlocutory appeal because that judge, a Ford appointee, had opposed intervention by individuals favoring affirmative action and therefore seemed unlikely to support the law school's substantive position. ${ }^{18}$ Republican appointees Batchelder and Boggs were motivated to take the highly unusual step of publicly criticizing their chief judge because of the political consequences of the chief judge's actions. ${ }^{19}$ Martin ultimately wrote the majority opinion for the en banc court, which split largely along party lines. ${ }^{20}$ Batchelder and Boggs

17. At the time of the en banc petition (May 14, 2001), six Democratic appointees and five Republican appointees sat on the Sixth Circuit Court: Carter appointee Martin; Reagan appointees Boggs and Norris; H.W. Bush appointees Suhrheinrich, Siler, and Batchelder; and Clinton appointees Daughtrey, Moore, Cole, Clay, and Gilman. See Federal Judicial Center, supra note 10, for biographies of each judge showing by which President each was appointed. If Martin expected all judges to vote along party lines, then the Democratic appointees would have had only a minimum-winning coalition. But the position of Clinton appointee Gilman may have been unclear because he joined the court after seventeen years on the faculty of the University of Memphis Law School. Federal Judicial Center, supra note 10 (search "Gilman, Ronald," then follow link). He ultimately voted against the University of Michigan Law School's admissions policy. Grutter, 288 F.3d at 815-18 (Gilman, J., dissenting) (concluding, consistent with Boggs's opinion, that the Law School's policy "results in a de facto quota" in violation of Bakke, but writing separately because he was "unpersuaded by [Boggs's] critique that no empirical link exists between a critical mass of minority students and the perceived educational benefits or [Boggs's] belief that race-neutral factors would be more likely to achieve the desired diversity of experience than reliance on an applicant's race").

18. See Grutter v. Bollinger, 188 F.3d 394, 401 (6th Cir. 1999) (Stafford, D.J., dissenting) (writing that the seventeen minority individuals and a nonprofit organization whose mission is to preserve opportunities in higher education for minorities should not be permitted to intervene). Senior District Judge William Stafford was appointed by President Ford to the Northern District of Florida. Federal Judicial Center, supra note 10 (search "Stafford, William," then follow link).

19. In his concurring opinion, Judge Clay not only questioned Boggs's stated reasons for publishing a procedural appendix, but also suggested that Boggs waited to complain until after "opinions had been circulated" and "votes cast" in the hope "that if [the dissent's] substantive basis for disagreement with the majority opinion [wa]s not convincing, then questioning the procedural posture" would be. Grutter, 288 F.3d at 772 (Clay, J., concurring). Judge Moore asserted that the dissent's "argument... that the decisions of this court are not grounded in principle and reasoned argument, but in power, and that the judges of this court manipulate and ignore the rules in order to advance political agendas" was baseless. Id. at 753 (Moore, J., concurring).

20. Id. at 735. Democratic appointees Martin, Daughtrey, Moore, Cole, and Clay voted to uphold the affirmative action program while Republican appointees Boggs, Siler, and Batchelder, along with Democratic crossover Gilman, voted to strike it. See id. (listing the concurring and dissenting judges, as well as the holding of the case). 
dissented. ${ }^{21}$ Martin's defense that he followed proper procedure indicates either an attempt to distract from his political motives or a lack of self-awareness. ${ }^{22}$

While the attitudinal model gains credence in law reviews, circuit judges assert that their seemingly political actions in fact are motivated by non-political goals, especially administrative ones. ${ }^{23} \mathrm{~A}$ managerial account of judicial decisionmaking focuses on a judge's workload as an overriding consideration-typically at the expense of the law. ${ }^{24}$ Many judges claim that merely staying on top of growing dockets is all-consuming and that speedy disposition is their highest priority. ${ }^{25}$ The circuit courts struggle to handle nearly 70,000 appeals filed annually with 179 authorized judgeships. ${ }^{26}$ For a chief judge, the

21. Judge Batchelder wrote a separate dissent for the sole purpose of specifically concurring in Boggs's procedural exegesis, saying, "Unless we expose to public view our failures to follow the court's established procedures, our claim to legitimacy is illegitimate." Id. at 815 (Batchelder, J., dissenting). In his dissent, Judge Siler did not concur in Boggs's inclusion of the procedural appendix. Id. (Siler, J., dissenting). Judge Gilman also separately dissented, confining his critique to the merits of the case, and conspicuously avoiding any mention of Boggs's discussion of internal procedure. Id. at 815.18 (Gilman, J., dissenting).

22. Judges, not surprisingly, have been less than satisfied with the attitudinalists' dismissal of their own accounts of their work. Chief Judge Harry T. Edwards of the D.C. Circuit argued:

Ignoring the self-description of judges would be one thing if judging were a mechanical process, or one performed by people incapable of self-consciousness. But judging is a human activity, performed by human beings trained to think critically about their endeavor. To understand it fully requires considering the way those who perform the activity understand it.

Harry T. Edwards, Collegiality and Decision Making on the D.C. Circuit, 84 VA. L. Rev. 1335, 1365 (1998). Attitudinalists are seeking to discern revealed, rather than stated, preferences. See generally SEGAL \& SPAETH, ATTTTUDINAL MODEL REVISITED, supra note 15.

23. The most vocal critic on the bench has been D.C. Circuit Judge Edwards, although he appears to have tempered his criticism. See, e.g., Edwards, supra note 22, at 1335-36 (1998) (writing to "debunk the myth that ideology is a principal determinant in decision making" and "to refute the heedless observations of academic scholars who misconstrue and misunderstand the work of the judges of the D.C. Circuit"); Harry T. Edwards, Public Misperceptions Concerning the "Politics" of Judging: Dispelling Some Myths About the D.C. Circuit, 56 U. Colo. L. REV. 619, 641 (1985) (seeking to "show that the increasingly popular image of the federal appellate courts as political bodies is a myth"); see also Gregory C. Sisk \& Michael Heise, Judges and Ideology: Public and Academic Debates about Statistical Measures, 99 Nw. U. L. REv. 743, 747-53 (2005) (discussing the debate between Edwards and legal scholars).

24. The managerial judging account was developed to describe how district judges have expanded their pre-trial role to achieve early resolution of cases through non-adjudicative processes rather than on the merits. See Judith Resnick, Managerial Judges, 96 HaRV. L. REV. $374,377-79$ (1982).

25. See Report of the Federal Courts Study Committee, 22 ConN. L. REv. 733, 744-48 (1990) (presenting, as part of the final report of a special committee appointed by the Chief Justice pursuant to Congressional authority, an examination of the caseload crisis on the federal courts of appeals).

26. See Administrative Office of the U.S. Courts, Annual Report of the Director: Judicial Business of the United States Courts 2005 Table B, http://www.uscourts.gov/judbus2005/ 
burden is particularly acute. Chief judges are expected to manage the oversized docket, ensuring speedy and just resolution of cases with limited resources, while also continuing to do the work of an active judge. Thus, the attitudinal story may be too narrow: its focus on judges as policy maximizers ignores how workload may actually prevent judges from considering policy.

The managerial judging account, like the attitudinal theory, has intuitive appeal. In Grutter, Chief Judge Martin's decision not to recall the district judge from Florida can be explained by a desire to limit costs and expedite the appeal. Martin assigned himself as a substitute in the interest of time and convenience because the case was on an expedited calendar and involved multiple parties and more than a dozen amici curiae. ${ }^{27}$ As to the timing of the en banc vote, Judge Clay argued:

It is ludicrous to think that with our circuit operating with only one-half of the active judges' positions filled, and with over 4000 cases reaching our Court each year, the Chief Judge or any members of this Court would single out any one particular case and maneuver the system for a particular outcome. ${ }^{28}$

The managerial judging story explains Chief Judge Martin's actions by looking to the rules and practices developed to handle a heavy caseload.

As Grutter demonstrates, chief judges' decisions offer an especially valuable lens through which to view the internal conflict between a judge's political goals and her notion of institutional responsibility. Other judges have accused their chiefs of political maneuvering, but such public accusations are rare. A paucity of these claims, however, does not necessarily mean that policy-oriented behavior is unusual. Chief judges may be too cautious (or wise) to use their powers in brazenly political ways, relying instead on less visible tools or informal powers to further their policy goals. Or their colleagues may fail to alert us to strategic behavior because they do not want to risk negative repercussions, create intracourt conflict, or use limited resources to complain. Or those colleagues may agree with the chief. If Judge Boggs had not taken the time to write a lengthy

appendices/b0.pdf, (reporting 68,743 filings for the term ending September 30, 2005); see also 28 U.S.C. $\$ 44(a)$ (2000) (authorizing a specific number of judgeships for each circuit).

27. As Judge Moore explained in her concurrence, "Although [the local] rule states that the third Sixth Circuit judge should be drawn at random, Chief Judge Martin has frequently substituted himself in a variety of matters ... in order to avoid inconveniencing other circuit judges." Grutter v. Bollinger, 288 F.3d 732, 757 (6th Cir. 2002) (en banc) (Moore, J., concurring).

28. Id. at 772 (Clay, J., concurring) ("Given the voluminous nature of the Court's docket and the shortage of judicial resources, the case management tasks performed by the Chief Judge are both necessary and appropriate, and were not in any sense improperly performed in relation to the instant case."). 
dissent, risking the alienation of his chief and colleagues, we would not have known about the Grutter conflict. How do we study a phenomenon that is generally invisible to the public? We propose looking at one highly visible action that may test the relative strengths of the attitudinal and managerial theories: the decision to leave the chief position.

Unlike the Chief Justice of the U.S. Supreme Court, who is nominated by the President and confirmed by the Senate to the position and therefore must retire from the Court to leave the post, chief circuit judges may step down from leadership but retain their judgeships (in active or senior status). Moreover, a chief judge, unlike the Chief Justice, may calculate who will replace her because chief judge succession is based on seniority. ${ }^{29}$ Given her options and information, a policy-oriented chief judge should time her departure to ensure a replacement or court that will continue to favor her policy preferences. If caseload pressures play a larger role in chief judges' decisions, however, a chief judge's early departure should be driven instead by increasing workload and related pressures from the position.

To evaluate the relative strengths of these explanations, we propose a strategic departure theory that draws on both attitudinal and managerial accounts and generates hypotheses regarding chief judge departure. We then test those hypotheses against a dataset that includes 112 chief judges who ended their tenure before January 1, 2007. The following picture emerges: chief judges are less attentive to policy goals as they are distracted by growing dockets and the concomitant growth in the body of case law. Put differently, the judicial utility function includes non-policy as well as policy concerns. Accordingly, we see chief judges completing a smaller and smaller fraction of their terms as caseloads grow larger and larger. This effect is particularly significant considering that the statutorily prescribed term limit is shorter now than it was twenty-five years ago. If we look only at the number of years a judge serves as chief, the drop-off is dramatic. ${ }^{30}$ These departures generally are not tied to any policy

29. A strategic departure occurred as this article was going to press: D.C. Circuit Chief Judge Douglas Ginsburg announced on January 24, 2008, that he was stepping down six months early and returning to active status. His early departure allowed Judge David Sentelle, who otherwise would have turned sixty-five before the end of Ginsburg's chief judge term, to succeed him. See Press Release, U.S. Court of Appeals for the D.C. Circuit (Jan. 24, 2008), available at http://www.cadc.uscourts.gov/internet/home.nsf/content/announcements (select "Press ReleaseNew Chief Judge beginning February 11, 2008") (on file with Vanderbilt Law Review).

30. See Table 1, infra p. 26 (listing the three distinct approaches that have been adopted over time: no term limits, an age limit of 70 , and a term limit of seven years or until the judge reaches 70 , whichever is earlier). 
outcomes; rather, they reflect relative workload. The exception may be seen in highly politicized circuits where the attitudinal model may have explanatory power. This intercircuit difference also highlights another problem with the attitudinal theory: most scholarship treats individual circuits as part of a single institution-the courts of appeals-rather than as a series of distinct though related institutions.

Part I examines the evidence of policy-oriented decisionmaking in federal courts. We consider how judges approach merits and nonmerits decisions and the relative influence of a judge's personal policy goals on both. We then consider the distinctive approach of the managerial model to the same decisions. Part II offers a history of the chief judge position, considering the opportunities for policymaking, as well as the possible constraints posed by management responsibilities. Part III presents a strategic departure model. We examine what attitudinal and managerial accounts predict about a chief judge's exercise of her authority. Part IV presents the results. If chief judges depart strategically, then we can infer that they believe their colleagues (or at least their opponents) will use judicial power to achieve policy goals and, further, that the chief judgeship is a tool for doing so. If chief judges depart for other reasons, then the attitudinal account's ability to explain judicial behavior is limited. Our results indicate only limited support for the attitudinal model and greater support for a managerial model, illustrating a paradoxical implication of managerial judging. Rather than leading to outcomes inconsistent with the law, chief judges' increasingly managerial role appears to diminish the likelihood that they behave attitudinally.

\section{INCENTIVES ON THE U.S. COURTS OF APPEALS}

Judges are at core human; thus, rational choice theory suggests that judges will take actions likely to help them achieve their goals (or maximize their utility). ${ }^{31}$ Classical legal theory assumes that judges want to reach the correct legal holding. ${ }^{32}$ Post-realist legal theory

31. See, e.g., Richard A. Posner, What Do Judges and Justices Maximize? (The Same Things Everybody Else Does), 3 SuP. CT. ECON. REv. 1 (1993).

32. Classical legal theory, or formalism, distinguishes judicial power from executive and legislative powers based on its lack of decisionmaking discretion. See, e.g., J. WOODFORD HOWARD, JR., COURTS OF APPEALS IN THE FEDERAL JUDICIAL SYSTEM: A STUdY OF THE SECOND, FIFTH, AND DISTRICT OF COLUMBIA CIRCUITS 15 (1981) (observing that, under the classic model of judicial function set forth by Alexander Hamilton and John Marshall, "judges do not make the law but merely declare it; judges exercise neither political power nor personal will but merely judgment, a process bridled by law and the discipline of a professional craft"); Thomas C. Grey, Langdell's Orthodoxy, 45 U. PITT. L. REV. 1, 1-5 (1983) (describing the origins and evolution of 
generally adheres to the same basic assumption, but also draws on other views of judicial decisionmaking for a richer view of judicial actors. ${ }^{33}$ Two positive theories may offer meaningful insight into the behavior of circuit judges: attitudinal theory and managerial judging theory. Attitudinal theory posits that judges desire to reach decisions consistent with their policy views. Managerial judging theory suggests that a predominant goal for contemporary judges is moving cases off the docket without regard to the law or, by implication, policy. We consider next what each theory predicts about the behavior of circuit judges.

\section{A. The Attitudinal Model}

Federal courts are policymaking institutions. Federal judges, then, make policy decisions. How do they decide? Legal scholars generally assume or argue that judges follow the law when making decisions. But much of legal scholarship focuses on disagreement or confusion over what the law provides. In those cases, judges have discretion. ${ }^{34}$ How do judges decide when they have a meaningful choice?

Traditional legal theory posits that judges will seek to discern the correct legal principle_or "find the law" or "do justice"-without regard to political views. ${ }^{35}$ To do so, judges may follow a specific jurisprudential approach. Any resulting disagreement between judges

classical legal orthodoxy beginning with the scientific theory of law espoused by Harvard Law School's first dean, Christopher Columbus Langdell).

33. See, e.g., KaRL N. Llewellyn, The COMmON LAW TradiTION: Deciding APPEALS (1960) (explaining and testing the primary themes of legal realism); see also Frank B. Cross, Political Science and the New Legal Realism: A Case of Unfortunate Interdisciplinary Ignorance, $92 \mathrm{Nw.}$ U. L. REV. 251, 255-64 (1997) (describing the influence of other ideas on legal theory but the continued acceptance of the idea that judges wish to follow prior decisions).

34. Even D.C. Circuit Judge Edwards, who has been highly critical of attitudinal models of judging, recognizes that judges have opportunities to reach decisions consistent with their policy preferences and will do so. See, e.g., Harry T. Edwards, The Role of a Judge in Modern Society: Some Reflections on Current Practice in Federal Appellate Adjudication, 32 CLEv. ST. L. Rev. $385,389-90,402$ (1983-1984) (explaining that, in a given term, judges will encounter a small percentage of cases in which the proper decision is sufficiently unclear that they will have to exercise discretion); see also BENJAMIN CARDOzo, The NATURE OF THE JudiCIAL PRocess 164-65 (1921) (describing judicial discretion as to law); R. Kent Greenawalt, Discretion and Judicial Decision: The Elusive Quest for the Fetters that Bind Judges, 75 CoLum. L. REv. 359, 377 (1975) (describing judicial discretion as existing when more than one possible answer has reasonably sound support).

35. See NEIL DUXBURY, PATTERNS OF AMERICAN JURISPRUDENCE 5 (1995) ("Judges ought to place their faith not in politics but in reason; and this requires that they endeavour to base controversial decisions on apolitical principles ... ."); Thomas C. Grey, Modern American Legal Thought, 106 YALE L.J. 493, 502-05 (1996) (book review) (discussing the belief held by classical legal thinkers that the judicial role is confined to deducing legal rules from basic principles). 
reflects a true dispute over what the law dictates, not merely a conflict in the judges' relative ideological positions. Standard doctrinal scholarship assumes that judges seek to reach "correct" results, but faulty reasoning may prevent judges from succeeding.

Political scientists have taken a different view. ${ }^{36}$ They too have sought to explain how federal judges make decisions. However, political scientists are writing from a background of studying elected bodies as institutions, rather than "the law" as an institution. ${ }^{37}$ Not surprisingly, they find political explanations for judicial disagreement. Armed with sophisticated methods, political scientists have offered empirical studies showing that judges, when possible, take positions that increase the probability of outcomes consistent with their ideology. ${ }^{38}$ The most clearly established relationship is between a judge's preferences and her votes on the merits of a case, as reflected in the most widely (though not universally) accepted model, the attitudinal model. More recent scholarship, often termed "new institutional" or "strategic," has expanded our understanding of judicial behavior, revealing policy-oriented decisions at other points in the legal process.

\section{The Role of Policy Preferences in Votes on the Merits}

The primary role of the judge is to resolve disputes brought to the court, whether between the State and a defendant or between

36. For an intellectual history of the political science study of the courts, see generally Lee Epstein, Jack Knight \& Andrew D. Martin, The Political (Science) Context of Judging, 47 ST. LOUIS U. L.J. 783 (2003).

37. See generally LaWrence Baum, The Puzzle of Judicial Behavior (1997); Sheldon Goldman \& Tom Jahnige, The Federal Courts as a Political System (3d ed. 1985). Legal scholars, unlike social scientists, frequently are guided by the desire to rationalize judicial policymaking in a democracy. Lawyers and legal academics help to legitimize Article III courts by presenting the judge as a neutral and reasoned decision maker and by emphasizing the primacy of rules. As Justice Felix Frankfurter explained the position: "Our judicial system is absolutely dependent upon a popular belief that it is as untainted in its workings as the finite limitations of disciplined human minds and feelings make possible." FELIX FRANKFURTER ON THE SUPREME COURT: EXTRAJUdICIAL ESSAYS ON THE COURT AND THE CONSTITUTION 78 (Philip Kurland ed., 1970).

38. The most cutting-edge work in political science is seeking not simply to explain past decisions but to predict future ones. Two political scientists, Andrew Martin and Kevin Quinn, joined forces with two law professors, Pauline Kim and Theodore Ruger, to test a multivariate forecasting model, in which a primary variable was ideological direction, against the predictions of legal experts. The model and the experts predicted the outcome of Supreme Court decisions for the 2002 Term. The model won. See Andrew D. Martin, Kevin M. Quinn, Theodore W. Ruger \& Pauline T. Kim, Competing Approaches to Predicting Supreme Court Decision Making, 2 PERSP. POL. 761, 761 (2004); Theodore W. Ruger, Pauline T. Kim, Andrew D. Martin \& Kevin M. Quinn, The Supreme Court Forecasting Project: Legal and Political Science Approaches to Predicting Supreme Court Decisionmaking, 104 COLUM. L. REv. 1150, 1150 (2004). 
private parties. An appellate judge's task is to review the decisions of lower court judges. ${ }^{39}$ The appellate judge generally faces a binary choice: affirm or reverse (or perhaps affirm in part and reverse in part). On a multi-judge panel, the judge votes and then authors or joins an opinion consistent with that vote. Attitudinal theory began as an effort to explain that primary decision, and its greatest success has been in explaining votes on the merits.

Attitudinal theory states that a judge, when possible, will vote for the outcome in a case that is closest to her policy position. ${ }^{40} \mathrm{~A}$ judge's personal policy preferences interact with the salient characteristics of a dispute, or "case stimuli," to produce a position on the appropriate outcome. ${ }^{41}$ Liberalness, or conservativeness, is the judge's "attitude" about what is at stake in the case. ${ }^{42}$ Hence, a liberal judge will vote in favor of the criminal defendant against the State because the judge's ideology includes certain views on the actions of the State and the rights of criminal defendants. ${ }^{43}$ Likewise, a conservative judge, for the same reasons, will vote against the criminal defendant. The analysis is the same in various other types of cases. $^{44}$

39. See Paul Carrington, Daniel J. MEador \& Maurice Rosenberg, Justice on Appeal 2 (1976) ("The traditional appeal calls for an examination of the rulings below to assure that they are correct, or at least within the range of error the law for sufficient reasons allows the primary decision-maker."); Roscoe POUND, APPELlate PROCEDURE IN CIVIL CASES 3-4 (1940) (describing appellate review as serving a two-fold function: error-correction and uniformity check).

40. See Tracey E. George \& Lee Epstein, On the Nature of Supreme Court Decision Making, 86 AM. POL. SCI. REv. 323, 326-28 (1992) (setting forth the attitudinal model and testing it against a legal model).

41. See Segal \& SPAeth, Attitudinal Model REvisited, supra note 15 , at $86.96,312$ (explaining the model's central tenet that "justices base their decisions on the merits on the facts of the case juxtaposed against their personal policy preferences").

42. Glendon Schubert, drawing on the work of social psychologists, was the first to propose a model of judicial decisionmaking based on Justices' attitudes. See GLENDON SCHUBERT, THE JUdicial MiND: THE ATTITUdES AND IDEOLOGIES OF SUPREME COURT JUSTICES, 1946-1963, at 5-6 (1965). David Rohde and Harold Spaeth expanded on Schubert's model with a construct of attitudes based on a set of interrelated beliefs and further observed that goals, rules, and situations influence judicial behavior generally. See generally DAVID W. ROHDE \& HAROLD J. SPAETH, Supreme Court Decision MAKIng (1976). For a discussion of Schubert's and Rohde and Spaeth's work, see SEgal \& SPAETH, ATTITUDINAL MODEL REVISITED, supra note 15, at 6769; Jeffrey A. Segal, Donald R. Songer \& Charles M. Cameron, Decision Making on the U.S. Courts of Appeals, in ConTEMPlating CourTs 227, 231-32 (Lee Epstein ed., 1995); Harold J. Spaeth, The Attitudinal Model, in ConTEMPLATING CoURTS, supra, at 296, 307.

43. See, e.g., Epstein, Knight \& Martin, supra note 36, at 794 (explaining that the attitudinal theory, which they note is only one theory and not theirs, states that "the votes of judges on the merits of cases will reflect their sincerely-held ideological (read: liberal or conservative) attitudes over particular matters of public policy" if those judges have life-tenure, agenda control, and the final word).

44. See, e.g., James J. Brudney, Sara Schiavoni \& Deborah Jones Merritt, Judicial Hostility Toward Labor Unions? Applying the Social Background Model to a Celebrated Concern, 60 OHIO 
The Supreme Court has been the primary focus of attitudinal studies. Justices have demonstrated a strong ideological influence on their votes on the merits. We can predict with remarkable accuracy the decision of an individual Justice in a particular case without knowing much about the relevant precedent. ${ }^{45}$ This idea initially may appear to undermine the central tenet of legal education: that learning how to reason logically from prior decisions equips lawyers to predict how judges will act in future cases. But the Supreme Court is not a typical court. The Justices control their agenda, granting certiorari to a tiny fraction of petitions. ${ }^{46}$ Hence, they largely are deciding cases for which the existing law is unclear, limited, or even nonexistent; that is, where the law does not clearly mandate an

ST. L.J. 1675, 1715 tbl.II (1999) (finding that Democratic circuit court appointees were much more likely than Republican appointees to favor unions); Sheldon Goldman, Voting Behavior on the United States Courts of Appeals Revisited, 69 AM. POL. SCI. REV. 491, 501 tbl.7 (finding evidence of ideological voting in a range of issue areas including criminal procedure, labor, private economic, and torts); Donald R. Songer \& Susan Haire, Integrating Alternative Approaches to the Study of Judicial Voting: Obscenity Cases in the U.S. Courts of Appeals, 36 AM. J. POL. SCI. 963, 976 tbl.2 (1992) (finding, after controlling for other factors, that Carter and Johnson appointees were significantly more likely than other appointees to support First Amendment speech rights in obscenity suits and that Reagan appointees were much less likely). See generally Daniel R. Pinello, Linking Party to Judicial Ideology in American Courts: A MetaAnalysis, 20 JUST. SYS. J. 219 (1999) (meta-analyzing 84 empirical studies of the relationship between judges' party identification and judicial decisions across a range of subjects, and concluding that party affiliation explains a substantial amount of the variance in the ideological direction of judicial decisions, particularly in federal courts (explaining $48 \%$ of the variance)).

45. Some research attempts to consider the influence of legally relevant facts as well as attitudes. But the definition of relevant facts is much narrower than that used in law, and the hypothesized influence is primarily in its relationship to the underlying views of the Justices. Hence, a Justice who generally favors broad police search power may consistently view homes as different from automobiles. See, e.g., George \& Epstein, supra note 40, at 328 (demonstrating that legally relevant variables as well as political ones have an effect on the decisions of Justices); Kevin McGuire, Obscenity, Libertarian Values, and Decision Making in the Supreme Court, 18 AM. POL. Q. 47, 47-53 (1990) (presenting a positive theory, including political and legal factors, of Supreme Court Justices' votes in obscenity cases); Jeffrey A. Segal, Predicting Supreme Court Cases Probabilistically: The Search and Seizure Cases, 1962-1981, 78 AM. POL. SCI. REV. 891, 892 (1984) (explaining that earlier fact-based models used to predict Supreme Court decisions were not very successful, as they incorporated more variables (including many facts) than cases, and that later attempts to improve these models concentrated on limiting the number of variables). From the attitudinal perspective, the nature of the action, rather than a particular doctrine, prompts a specific ideological response. See SEGAL \& SPAETH, ATTITUDINAL MODEL REVISITED, supra note 15, at 312-14 ("To phrase the matter from the standpoint of attitude theory [whose intellectual origin is psychology,] . . . behavior may be said to be a function of the interaction between an actor's attitude toward an 'object' (i.e., persons, places, institutions, and things) and that actor's attitude toward the situation in which the object is encountered." (quoting MILTON ROKEACH, BELIEFS, ATTITUDES AND VALUES: A THEORY OF ORGANIZATION AND CHANGE 112-22 (1968))).

46. See Tracey E. George \& Michael E. Solimine, Supreme Court Monitoring of the United States Courts of Appeals En Banc, 9 SUP. CT. ECON. REV. 171, 171 (2001) (reporting that the Supreme Court grants review to less than $4 \%$ of paid petitions). 
outcome. ${ }^{47}$ Given such discretion, Justices have significant freedom to vote their policy preferences-and they do.

The U.S. Courts of Appeals are less frequently a part of attitudinal studies and also are less likely to support attitudinal hypotheses. The majority of circuit cases allow little decisionmaking discretion. While estimates vary, judges and scholars agree that more than half (and perhaps as much as three-quarters) of the circuit docket presents "easy" questions. ${ }^{48}$ A judge's decision is easy because existing law is undisputed or the standard of review is highly deferential or both. In those cases, a judge's policy goals lose out to other goals, including avoiding the embarrassment of en banc or Supreme Court reversal, limiting time spent on uninteresting or marginal disputes, and building collegiality with colleagues. The attitudinal theory is not weakened by this fact because it does not claim to explain constrained decisionmaking.

Attitudinal theory, if robust, should be able to explain the decisions of appellate judges on circuit courts when they are deciding under circumstances akin to those characterizing the Supreme Court. An obvious example is en banc decisions. While the circuit courts have little discretion over the cases they must assign to three-judge panels for review, they have complete discretion over the cases they decide as an entire body. ${ }^{49} \mathrm{~A}$ majority of active judges must vote to grant en banc hearing. This selection process creates a presumption that the

47. For a discussion of the Court's exercise of its agenda control, see H.W. PERRY, DECIDING to Decide: Agenda SeTting in the United States Supreme Court (1991), and Lawrence A. Baum, Case Selection and Decisionmaking in the U.S. Supreme Court, 27 LAW \& SOC'Y REV. 443 (1993).

48. See, e.g., Edwards, supra note 34. Based on his experience as a D.C. Circuit judge, Edwards estimated "that approximately one-half of the cases decided are easy; the pertinent legal rules seem to me unambiguous and their application to the facts appears clear." He then added, regarding the remaining one-half of the cases:

A dispute falling into this category, I believe, admits of only one "right answer"... [in the remaining one-half], the answers are not so clear. In only a relatively small subset of these, however, do I feel I may and must exercise what I will call "discretion." Using rough numbers, I would say that in only five to fifteen percent of the disputes that come before me do I conclude... that to dispose of the appeal I must rely on some significant measure of discretion.

Id. Edwards describes the remaining subset as "hard cases," and allows that judges may be influenced in such cases by their views on the underlying social issue. Id.; see also J. Edward Lumbard, Current Problems of the Federal Courts of Appeals, 54 CORNELL L. REV. 29, 36 (1968) (asserting that " $[\mathrm{m}]$ ost appellate judges would agree that the result in about seventy-five per cent of appeals is clearly foreseeable after argument, regardless of which judges sit on those cases," but that the remaining $25 \%$ are close cases).

49. See 28 U.S.C. $\S \S 44,46$ (2000) (providing statutory authority for en banc sittings); FED. R. APP. P. 35 (providing procedural rules governing en banc hearings). For a detailed discussion of the history and modern use of en banc review, see generally Tracey E. George, The Dynamics and Determinants of the Decision to Grant En Banc Review, 74 WASH. L. REV. 213 (1999). 
cases are more likely to involve difficult, complex, highly political, or at least important questions. That is, en banc cases should, like Grutter, be similar to those heard by the Supreme Court. Indeed, empirical studies have found that circuit judges in en banc cases exhibit the same relatively predictable decisionmaking process as Justices on the Supreme Court. ${ }^{50}$

If attitudinal theory explained circuit judge behavior only in en banc cases, it would offer limited insight into the actions of those judges because en banc rulings, while among the most significant, are rare. ${ }^{51}$ But attitudinalists also have had success explaining the votes of judges in other cases that likely involve discretion. Because circuit judges are constrained by precedent when it is clear, they should disagree primarily when the law is murky and they must rely on discretion. By focusing on cases in which a panelist dissents or a unanimous panel disagrees with a district judge, scholars have found additional evidence of ideological voting. ${ }^{52}$ The results are most dramatic in appeals raising politicized issues such as civil rights and liberties, criminal law, and labor law. ${ }^{53}$ In these politically salient

50. See George, supra note 16 , at $1678-86$ (explaining that empirical studies of the internal and external influences on Supreme Court Justices "have merit in the context of the en banc courts of appeals"); Christopher P. BANKS, JUdiClal POLITICS IN THE D.C. CiRCUIT 88 (1999) (discussing the fact that "[w]hile en banc review and appeal to the Supreme Court are distinct judicial conventions, both still involve the use of discretion that is political").

51. See George \& Solimine, supra note 46, at 176-78 figs.1 \& 2, 200 app.1 (estimating that less than one percent of cases are heard en banc); see also A. Lamar Alexander, Jr., Note, En Banc Hearings in the Federal Courts of Appeals: Accommodating Institutional Responsibilities (Part I), 40 N.Y.U. L. REv. 563, 564, 608 app.IV (1965) (finding that only 423 cases were decided en banc by all circuits from 1940 to 1964 , and that only $1.5 \%$ of decisions in 1964 were rendered en banc).

52. See, e.g., Virginia A. HetTINGer, Stefanie A. Lindquist \& WEndy L. MARTinek,

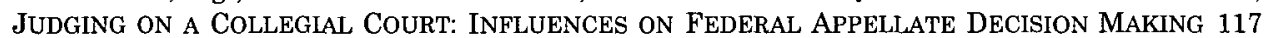
(2006) ("The scholarship devoted to appellate reversal strongly indicates that the match (or mismatch) of preferences between reviewing judges and those under review matters a great deal."); Brudney, Schiavoni \& Merritt, supra note 44, at 1736-37 (finding that judicial attributes are more influential in predicting outcomes on politically divisive issues as compared to nondivisive issues); Goldman, supra note 44, at 491, 504 (conducting an examination of nonunanimous courts of appeals decisions to find judicial behavior representing political and economic attitudes); Donald R. Songer, Consensual and Nonconsensual Decisions in Unanimous Opinions of the United States Courts of Appeals, 26 AM. J. POL. SCI. 225, 225 (1982) (observing that most appellate court research looks only at divided decisions).

53. See, e.g., Donald R. Songer \& Sue Davis, The Impact of Party and Region on Voting Decisions in the United States Courts of Appeals, 1955-1986, 43 W. POL. Q. 317, 327-28 (1990) (hypothesizing that new political issues may explain the increased partisan effects on judges); Songer \& Haire, supra note 44, at 978 (arguing that judges may respond differently to politically sensitive or divisive issues like those presented in civil liberties cases than to other issues on their agenda). 
areas, circuit judges appear affected by ideology even in unanimous decisions. ${ }^{54}$

\section{The Role of Policy Preferences in Non-Merits Decisions}

It seems noncontroversial that a judge's votes on the merits in close cases will be related to the judge's policy preferences. First, the relationship between the judge's vote and the outcome in the case is clear. Second, a judge's ideology is most relevant in cases where the judge has some discretion. But are judges strategic? Will they consider policy when making decisions that indirectly affect outcomes? If judges are policy-oriented, then all of their actions should be influenced, in part, by policy consequences.

Policy may actually play a greater role in decisions not clearly connected with case outcomes. While judges may express policy preferences more easily through votes on the merits, such votes are transparent, and purely political motives are easy to detect. ${ }^{55}$ Thus a judge might choose less direct methods to pursue attitudinal goals because she can do so with decreased risk of discovery. Such veiled acts also can be difficult for researchers to discover. Fortunately, we have found some visible actions that would reflect an underlying attitudinal motive if one exists. Various studies have examined the degree to which judges calculate the policy consequences of decisions to hear cases, ${ }^{56}$ to write opinions, ${ }^{57}$ and to retire. ${ }^{58}$

Agenda control is a crucial power for policymaking bodies. It allows them to determine which issues to address, as well as when

54. Legal scholar Richard Revesz, for example, has found this to be true for D.C. Circuit judges in regulatory cases. See, e.g., Richard L. Revesz, Environmental Regulation, Ideology, and the D.C. Circuit, 83 VA. L. REV. 1717, 1771-72 (1997).

55. For example, another judge on a panel may blow the whistle on a colleague who votes ideologically. See, e.g., Frank B. Cross \& Emerson H. Tiller, Judicial Partisanship and Obedience to Legal Doctrine: Whistleblowing on the Federal Courts of Appeals, 107 YALE L.J. 2155, 2173-76 (1998) (describing the phenomenon and proposing a panel assignment system that ensures the presence of a watchdog judge on each panel).

56. For Supreme Court studies, see, for example, Jeffrey A. Segal \& Robert Boucher, Supreme Court Justices as Strategic Decision Makers: Aggressive Grants and Defensive Denials on the Vinson Court, 57 J. PoL. 824 (1995). For courts of appeals studies, see, for example, Micheal Giles, Thomas Walker \& Christopher Zorn, Setting a Judicial Agenda: The Decision to Grant En Banc Review in U.S. Courts of Appeals, 68 J. POL. 852 (2006).

57. For Supreme Court studies, see, for example, LEE EPSTEIN \& JACK KNIGHT, THE CHOICES JUSTICES MAKE (1998). For courts of appeals studies, see, for example, HETTINGER, LINDQUIST \& MARTINEK, supra note 52.

58. For Supreme Court studies, see, for example, Timothy M. Hagle, Strategic Retirements: A Political Model of Turnover on the United States Supreme Court, 15 POL. BEHAV. 25 (1993). For courts of appeals studies, see, for example, Albert H. Yoon, Pensions, Politics, and Judicial Tenure: An Empirical Study of Federal Judges, 1869-2002, 8 AM. L. \& ECON. REV. 143 (2006). 
and how to do so. The Supreme Court sets its agenda through the highly selective certiorari process. ${ }^{59}$ Policy-minded Justices should be more likely to vote to grant certiorari when they disagree with the ideological direction of the lower court's decision, or when socially important issues are at stake. Indeed, studies have found that attitudinal factors, along with other variables, explain most Supreme Court certiorari grants. ${ }^{60}$ Unlike Justices, circuit judges spend most of their time deciding cases on their mandatory docket, but they have complete discretion over the cases heard en banc. Circuit judges appear to use their agenda-setting power, the decision to grant en banc review, in the same way Justices use their agenda-setting power, the decision to grant certiorari. ${ }^{61}$

Appellate judges must vote in every case, but authoring or joining an opinion is a choice. What explains a judge's decision to sign onto an opinion or to write separately? Walter Murphy may have been the first to observe, based on an examination of Justices' papers, the intra-Court bargaining whereby a Justice offers to trade her vote and concurrence in an opinion for changes in the content of the opinion. ${ }^{62}$ This strategic account focuses on the collective nature of federal appellate courts, where bargaining, compromise, and accommodation are necessary for judges to affect outcomes. That is, a policy-oriented judge will rationally vote contrary to her preferred position if it moves the majority's position closer to her own. ${ }^{63}$ While it rejects the sincere

59. Since the Judiciary Act of 1925 , the Supreme Court has had an extremely limited original jurisdiction which accounts for only a handful of cases each year. For a history of the Supreme Court's certiorari policy and relevant statistics, see RICHARD H. FALLON ET AL., HART \& WECHSLER'S THE FEDERAL COURTS AND THE FEDERAL SYSTEM 1580-1612 (5th ed. 2003).

60. See, e.g., Charles M. Cameron, Jeffrey A. Segal \& Donald Songer, Strategic Auditing in a Political Hierarchy: An Informational Model of the Supreme Court's Certiorari Decisions, 94 AM. POL. SCI. REV. 101, 101 (2000) (developing and testing a strategic model of Supreme Court certiorari decisions where the Court responds to signals and indices from courts of appeals, termed a "judicial signaling game," and finding that a conservative Court was more likely to review liberal decisions by liberal lower courts); Richard L. Pacelle, Jr., The Dynamics and Determinants of Agenda Change in the Rehnquist Court, in CONTEMPLATING COURTS, supra note 42, at 251, 251-53 (discussing research demonstrating that "[ $t]$ he factors that govern the selection of cases and the construction of an annual agenda are closely tied to the factors that explain the justices' decisions on the merits of cases").

61. See George, supra note 49 , at 236-72 (finding that courts were more likely to rehear cases en banc when the ideological direction of a panel's decision was contrary to the circuit's, the ideological composition of the panel was different from the circuit's, and/or the panel was divided or reversed the district court); Giles, Walker \& Zorn, supra note 56, at 852-65 (analyzing "the influence of ideological and legal factors on the grant of en banc rehearing in the U.S. Courts of Appeals-one of the few instances of agenda control in the lower federal courts").

62. See Walter MURPHy, Elements of STRATEgy 56-68 (1964) (documenting vote-trading exchanges reflected in the papers of Justices Murphy, Stone, and Taft).

63. For empirical evidence from the Supreme Court, see EPSTEIN \& KNIGHT, supra note 57; Forrest Maltzman, James F. SPriggs II \& Paul J. WAHLbeck, Crafting LaW on the Supreme 
voting assumption of the attitudinal model, the strategic model builds on the same core idea: judges make decisions to further their policy goals, and one such decision is coalition formation.

Federal appellate judges have life tenure. ${ }^{64}$ They may leave the court voluntarily or die in office. A policy-oriented judge should try to time her departure to increase the probability of a like-minded replacement. Consistent with the attitudinal and strategic models, scholars have found that Supreme Court Justices are "keenly aware of the importance of membership change on the Court's decisions" and that political factors play a significant role in Justices' decisions to remain on or leave the Court. ${ }^{65}$ The evidence on circuit judges, by contrast, is less clear. Studies have found that circuit judges are more likely to retire when they share the same political affiliation as the sitting President.66 But financial considerations-in particular, pension qualification-appear to play a larger role than political ones. ${ }^{67}$

The attitudinal theory offers crucial insights into judicial behavior and has proven to be a rigorous model of appellate judicial decisionmaking. The model, however, fails to respond to one of the most dramatic recent changes in the work of appellate courts: a nearly

Court: The Collegial Game 57-76 (2000). For empirical evidence from the courts of appeals, see HETTINGER, LINDqUIST \& MARTINEK, supra note 52 at 75-78.

64. U.S. CONST. art. III, $\S 1$.

65. See Gary King, Appointments to the Supreme Court: Adding Systematic Explanation to Probabilistic Description, 15 AM. POL. Q. 377, 383-84 (1987) (finding that Justices time retirements to occur at an ideologically optimal time); Christopher J.W. Zorn \& Steven R. Van Winkle, A Competing Risks Model of Supreme Court Vacancies, 1789-1992, 22 POL. BeHAV. 145, 146-50 (2000) (finding that political factors, along with personal considerations and institutional influences, explain Justices' tenure decisions). But see Richard L. Vining, Jr., Christopher Zorn \& Susan Navarro Smelcer, Judicial Tenure on the U.S. Supreme Court, 1790-1868: Frustration, Resignation, and Expiration on the Bench, 20 STUD. AM. POL. DEV. 198, 207-10 (2006) (reporting that institutional and personal factors, such as finances and health, played a much larger role than political ones in the tenure decisions of early Justices). While Justices, including the Chief Justice, may seek to time their departures to affect who replaces them, they are working with complex probabilistic determinations. A Chief Justice may choose to step down under a specific President in hopes that his replacement will hold the President's ideological positions. This will depend on both the nomination and confirmation processes as well as the new appointee's actual behavior on the Court. The Chief Justice, then, does not have the chief judge's luxury of predicting with near certainty the judicial behavior of his replacement. In fact, a Chief Justice may not even be correct in predicting the President who will replace him, as Earl Warren learned to his dismay.

66. See Deborah Barrow \& Gary Zuk, An Institutional Analysis of Turnover on the Lower Federal Courts, 1900-1987, 52 J. PoL. 457, 464, 466-73 (1990); James F. Spriggs II \& Paul J. Wahlbeck, Calling It Quits: Strategic Retirements on the Federal Courts of Appeals, 1893.1991, 48 POL. RES. Q. 573, 573, 577, 588-90, 592 (1995).

67. See Albert H. Yoon, Love's Labor's Lost: Judicial Tenure Among Lower Federal Court Judges, 1945-2000, 91 CAL. L. REV. 1029, 1041, 1045.49, 1052, 1056-57 (2003) (presenting evidence from an empirical study of judicial tenure decisions). 
overwhelming growth in caseload. Combining data over a large period fails to take into account the ability of judges to focus on policy as they must decide more cases and keep track of a rapidly expanding body of case law. Moreover, models rarely include variables related to the changing workload of the courts. We contend that the managerial judging concept provides a positive account of judging on appellate courts because it considers the possible effects of the work environment of judging.

\section{B. The Managerial Judging Model}

The attitudinal model counters the legal model's impartial jurist paradigm by revealing the influences of policy preferences on judicial decisionmaking. The managerial judging model also questions this paradigm, but on the basis of workload. Although the managerial judging theory shares the attitudinal theory's focus on judges as rational actors, it predicts that judges seek to maximize much different preferences. That is, judges desire to move cases off the docket and have a sense of control over workload.

The attitudinal and strategic models largely ignore evidence that appellate judges are increasingly guided by non-policy goals as a result of workload. ${ }^{68}$ Or they characterize certain actions-increased use of summary dispositions, decreased grants of en banc and certiorari petitions, limiting or refusing oral argument, or the nonpublication of opinions-as the product of specific policy views. The difficulty is that these varied acts lack a consistent ideological correlate. They span issue areas, case types, and parties. The appellant-whether a corporation or an underdog-is less likely to receive meaningful review of the trial court's judgment in a world of managerial appellate judges.

Judith Resnick coined the term "managerial judges" to describe the modern role of trial judges in the federal courts. ${ }^{69}$ Facing a "mountain of work," district judges have embraced the tools created by the Federal Rules of Civil Procedure to persuade, cajole, and even coerce parties to end suits quickly. ${ }^{70}$ Resnick carefully distinguishes

68. But see Ahmed Taha, Publish or Paris? Evidence of How Judges Allocate Their Time, 6 AM. L. \& ECON. REV. 1, 20 (2004) (considering the influence of workload and other variables on district judge decisions to publish opinions, and finding that lower caseload, controlling for other variables, increased the probability that a judge published an opinion).

69. See Resnick, supra note 24, at 378; see also Maximo Langer, The Rise of Managerial Judging in International Criminal Law, 53 AM. J. COMP. L. 835, 874.85 (2005) (describing Resnick's managerial model).

70. Resnick, supra note 24 , at $378-80$. 
justifiable actions made necessary by changes in the law from those "initiated by the judges themselves in response to workload pressures."71 Resnick offered her model as an empirically informed critique of modern case management practices, but her ideas extend beyond that purpose and that application. ${ }^{72}$

Appellate judges have adjusted their practices and even their rules to resolve more cases and to do so more quickly, often at the expense of merits consideration. For example, circuits have increased their reliance on staff attorneys to screen cases and suggest decisions, have limited the time for oral argument and even its availability, and have strictly enforced technical rules to move cases off the docket. ${ }^{73}$ And the decreasing publication of opinions has reduced the value of appeal for litigants on both sides: a successful public interest law group fails to get precedent on which to build a new legal doctrine, and successful established interests are left without citable cases to use in foreclosing future suits. ${ }^{74}$ While those who favor the status quo may be better off with managerial judging, the advantage is not sufficient to support an attitudinal account of these actions.

\section{LEADERSHIP ON THE LOWER FEDERAL COURTS}

The Chief Justice of the Supreme Court is the "first among equals," or at least he can be. ${ }^{75}$ Specific Court eras frequently are

71. Id. at 391 .

72. Ahmed Taha's incorporation of the workload variable into a study of district judge's opinion publication decisions is an example. Taha, supra note 68, at 6, 13,25. Maximo Langer has applied the model to international criminal proceedings. Langer, supra note 69.

73. See, e.g., Richard J. Cardamone, Foreword: How an Expanding Caseload Impacts Federal Appellate Procedures, 65 BROOK. L. REV. 281, 286.90 (1999); William L. Reynolds \& William M. Richman, Studying Deck Chairs on the Titanic, 81 CoRnelu L. REV. 1290, 1290, 1293 (1996); William M. Richman \& William L. Reynolds, Elitism, Expediency, and the New Certiorari: Requiem for the Learned Hand Tradition, 81 CORNELL L. REV. 273, 279-92 (1996).

74. See, e.g., Penelope Pether, Inequitable Injunctions: The Scandal of Private Judging in the U.S. Courts, 56 STAN. L. REV. 1435, 1442-83 (2004) (describing the history and current state of nonpublication in appellate courts and the dangers that the practice presents); Sarah E. Ricks, The Perils of Unpublished Non-Precedential Federal Appellate Opinions: A Case Study of the Substantive Due Process State-Created Danger Doctrine in One Circuit, 81 WaSH. L. REV. 217, 228-35 (2006) (arguing that unpublished opinions "create] a number of risks for courts and litigants, including: doctrinal shifts from precedential decisions; uncertainty about the persuasive value of non-binding decisions issued by the hierarchically superior court; mistaken predictions of an opinion's future usefulness; and unpredictability of judicial outcomes"); David C. Vladeck \& Mitu Gulati, Judicial Triage: Reflections on the Debate Over Unpublished Opinions, 62 WASH. \& LEE L. REV. 1667, 1676-90 (2005) (arguing against the use of unpublished opinions because it "provides incentives for strategic game-playing by appellate courts and sophisticated appellate lawyers").

75. David J. Danelski, The Influence of the Chief Justice in the Decisional Process, in American Court Systems: Readings in Judicial Process ANd Behavior 506, 506 (Sheldon 
known by the name of the Chief: the "Warren Court" is a short-hand for numerous landmark decisions as well as a particular jurisprudential philosophy. ${ }^{76}$ The Chief Justice's institutional responsibilities can have clear political implications. ${ }^{77}$ The Independent Counsel statute granted nearly unfettered discretion to the Chief Justice to appoint a panel that, in turn, named the Independent Counsel. ${ }^{78}$ Other less obviously political powers, such as opinion assignment when in the majority and the conference privilege of speaking first and voting last, carry substantial policy import. ${ }^{79}$

The circuit chief judge, by contrast, may appear as only "one among equals." 80 Circuit court eras are not known by the names of

Goldman \& Austin Sarat eds., 1978) (arguing that Chief Justices have the potential to exert both "social" and "task" leadership). Various qualitative and quantitative studies have demonstrated the potential and real influence of Chief Justices. See, e.g., Frank B. Cross \& Stefanie Lindquist, Doctrinal and Strategic Influences of the Chief Justice: The Decisional Significance of the Chief Justice, 154 U. PA. L. REv. 1665 (2006) (studying the effect that Chief Justices Rehnquist and Burger had on the decisionmaking of their respective courts); Sue Davis, The Chief Justice and Judicial Decision-Making: The Institutional Basis for Leadership on the Supreme Court, in SUPREME COURT DECISION-MAKING: NEW INSTITUTIONALIST APPROACHES 135 (Cornell W. Clayton \& Howard Gillman eds., 1999) (examining the influence of Chief Justice Rehnquist); Joseph F. Kobylka, Leadership on the Supreme Court of the United States: Chief Justice Burger and the Establishment Clause, 42 W. POL. Q. 545 (1989) (arguing that Chief Justice Burger, for many reasons, failed to lead the court effectively).

76. See, e.g., Morton J. Horwitz, The WarRen Court and the Pursuit of Justice (1998); Bernard SchWartz, Super ChIEF: Earl Warren and His Supreme Court-A Judicial BIOGRAPHY (1983).

77. See, e.g., Theodore W. Ruger, Chief Justice Rehnquist's Appointments to the FISA Court: An Empirical Perspective, 101 NW. U. L. REV. 239 (2007) (exploring the ideological views of the Chief Justice's appointees to this controversial court).

78. The Independent Counsel statute, 28 U.S.C. $\$ \S 591-99$ (2000), delegates to a special three-judge panel the power to appoint the Independent Counsel and to oversee the counsel's work. Id. $\S \S 591,593$. The Chief Justice names the judges to that panel. Id. $\S 49$ (d) ("The Chief Justice of the United States shall designate and assign three circuit court judges or justices, one of whom shall be a judge of the United States Court of Appeals for the District of Columbia, to such division of the court. Not more than one judge or justice or senior or retired judge or justice may be named to such division from a particular court."). Chief Justice Rehnquist selected two conservative judges-D.C. Circuit Judge David Sentelle and Eleventh Circuit Judge Peter Fayand one liberal judge-Fourth Circuit Senior Judge John Butzner-to the panel that ultimately chose Ken Starr. John Q. Barrett, Special Division Agonistes, 5 WIDENER L. SyMP. J. 17, 44-47 tbl.1 (2000) (listing the judges who have served on the special division and the independent counsel appointed by each such division).

79. See, e.g., Kobylka, supra note 75 (enumerating, in his examination of Chief Justice Burger's failure to lead the Court, the ways in which a Chief Justice may influence his colleagues and the Court); Forrest Maltzman \& Paul J. Wahlbeck, A Conditional Model of Opinion Assignment on the Supreme Court, 57 POL. RES. Q. 551, 559-61 (2004) (finding that Chief Justices are likely to use opinion assignments to further policy goals when the conference majority is greater than five, the case is important, and the assignment is made earlier in the term).

80. Second Circuit Chief Judge Edward Lumbard made this claim in an article advocating for certain changes in court policy and structure. He characterizes circuit chief judges in this way 
their chiefs. ${ }^{81}$ A chief judge's administrative duties often appear significant in their demand on a chief's time but merely bureaucratic in their likely effect on court decisions. ${ }^{82}$ The chief must oversee the circuit's budget, monitor the hiring and firing of staff, and deal with the numerous requests for building improvements and equipment. ${ }^{83}$ However, as we know from studies of administrative agencies, seemingly benign administrative power can affect substantive outcomes. ${ }^{84}$

Chief judges hold many institutional powers, including day-today management of a federal court of appeals, which may be used to further a particular agenda. ${ }^{85}$ They oversee the assignment of judges to panels and panels to cases, ${ }^{86}$ request visiting judges from other circuits, ${ }^{87}$ manage the participation of senior (semi-retired) judges, ${ }^{88}$

because they must persuade their colleagues to agree to any decision (at least enough other judges to create a majority). Interestingly, his discussion makes clear that he had particular luck doing so. Lumbard, supra note 48 , at 42.

81. One exception might be Learned Hand's leadership of the Second Circuit during the 1940 s and early 1950s, which has led some to call it the Hand court. E.g., MARVIN SCHICK, LEARNED HAND'S COURT (1970).

82. See Will Shafroth, Survey of the United States Courts of Appeals, 42 F.R.D. 243, 284 (1967) (reporting, based on a 1966 survey of all circuit judges, that "[t]he Chief Judges all have heavy administrative duties on which they spend from one-third to one-half their time").

83. See id.; Federal Judicial Center, Template for ChiEf Circuit Judges' Deskbook 12-17 (2001) [hereinafter CHIEF CIRCUIT JUDGES' DESKBOOK] (describing the circuit-wide administrative duties assigned to the chief judge).

84. See, e.g., William A. NiSkanEn, JR., BUREAUCRACY AND REPRESENTATIVE Government (1971) (arguing that bureaucrats are able to use their power to impose their preferences upon the legislature); Cheryl L. Eavey \& Gary J. Miller, Bureaucratic Agenda Control: Imposition or Bargaining?, 78 AM. POL. SCI. REV. 719, 730 (1984) (finding support for a bureaucratic-legislative bargaining theory); Thomas H. Hammond, Agenda Control, Organizational Structure, and Bureaucratic Politics, 30 AM. J. POL. SCI. 379 (1984) (examining how bureaucratic structure influences the inner workings and policy output of administrative agencies).

85. See generally CHIEF CIRCUIT JUDGES' DESKBOOK, supra note 83 (providing a description of the duties performed by circuit judges).

86. Congress has authorized circuits to decide cases in three-judge panels, but it has not addressed the process of assigning judges to those panels, except for the Federal Circuit. 28 U.S.C. $\S 46$ (b) (2000). Chief judges have statutory authority to assign visiting, senior, and designated district judges to panels, $i d$. $\S \S 292,294,295$, and oversee circuit staff. $I d$. $\S 332$. Not surprisingly, then, chiefs have varying degrees of discretion and responsibility for the panel assignment process. Chief Judge Wilfred Feinberg, for example, reported that "[i]n the Second Circuit, it is the responsibility of the chief judge to select and organize the composition of the panels of three judges." Wilfred Feinberg, The Office of Chief Judge of a Federal Court of Appeals, 53 FoRDHAM L. REV. 369, 374 (1984). For a detailed examination of individual circuit practices (with particular consideration of the power of the chief judge), see Professor Jay Brown, Circuit Practices (Jan. 1, 2000) (unpublished appendix to J. Robert Brown, Jr. \& Allison Herren Lee, Neutral Assignment of Judges at the Court of Appeals, 78 TEX. L. REV. 1037 (2000)), available at http://www.law.du.edu/jbrown/courts/Default.htm (follow "Circuit Practices" link).

87. 28 U.S.C. $\$ 293$.

88. Id. $\S 294$. 
designate district judges to sit on the circuit, ${ }^{89}$ and control special three-judge district court panels. ${ }^{90}$ Chief judges also manage court councils, create ad hoc committees to consider institutional questions, and represent the court in various settings. Moreover, chief judges continue to hear cases. ${ }^{91}$ The chief is always the most senior judge on a panel, including an en banc sitting, allowing the chief, if in the majority, to assign the opinion..$^{92}$

\section{A. The Creation and Selection of Chief Judges}

Chief judges are relatively new to the lower federal courts. The first Judiciary Act established a Chief Justiceship for the Supreme Court ${ }^{93}$ and created lower courts. ${ }^{94}$ But Congress did not establish a leadership position for these new "district" and "circuit" courts. The Evarts Act of 1891 created the circuit courts of appeals and assigned the most senior judge on a three-judge circuit panel the role of presiding judge. ${ }^{95}$ However, the Act delegated administrative powers-such as hiring a court clerk and marshal, creating internal operating procedures, and designating district judges to sit on panels-to the circuit court of appeals as a whole..$^{96}$ Thus, the judges collectively controlled the day-to-day operations.

In 1914, Yale Law Professor William Howard Taft, the former President and Sixth Circuit judge, advocated for the establishment of

89. Id. § 292 .

90. Id. $§ 2284$.

91. See Patricia M. Wald, . . Doctor, Lawyer, Merchant, Chief, 60 Geo. WASH. L. REv. 1127, 1130 (1992) ("Many, if not most, Chief Judges maintain a full calendar of cases as I did . . .."); cf. RUSSELL R. WHEELER \& CHARLES W. NIHAN, ADMINISTERING THE FEDERAL JUDICIAL CIRCUITS: A SURVEY OF CHIEF JUDGES' APPROACHES AND PROCEDURES 6 tbl.1 (1982) (reporting, based on interviews of every chief judge and circuit executive, that only four of twelve chief judges heard fewer cases than they heard prior to becoming chief judge).

92. 28 U.S.C. $\S 45(\mathrm{~b})$ ("The chief judge shall have precedence and preside at any session of the court which he attends. Other circuit judges of the court in regular active service shall have precedence and preside according to the seniority of their commissions. Judges whose commissions bear the same date shall have precedence according to seniority in age. The circuit justice, however, shall have precedence over all the circuit judges and shall preside at any session which he attends.").

93. Judiciary Act of 1789 , ch. $20, \S 1,1$ Stat. 73.

94. See id. The Act created "district" and "circuit" courts. Both acted essentially as trial courts although the circuit courts had some limited appellate authority over districts courts. District courts acted through a single judge, while circuit courts acted through a three-judge panel comprised of one district judge and two Supreme Court Justices. Id.

95. See Evarts Act of 1891 , ch. $517, \S \S 2-3,26$ Stat. 826, 826-27. Seniority was first by court of appointment (Justice over circuit judge over district judge), and then by time of appointment. Id. $\S 2,26$ Stat. at 827 .

96. Id. $\S \S 2-3,26$ Stat. at 826-27. The Attorney General had responsibility for obtaining physical space for judges to work and hear cases. Id. $\S 9,26$ Stat. at 829 . 
court leadership. ${ }^{97} \mathrm{He}$ argued that Congress should grant certain judges management responsibility and control over court dockets and related tasks. ${ }^{98}$ Shortly after his appointment to the Supreme Court in 1921, Chief Justice Taft finally persuaded Congress to create an organization consisting of the most senior judge from each circuit. ${ }^{99}$ The new Judicial Council met annually to craft procedure and standards for handling judicial business. The Council also proposed legislation on federal jurisdiction and procedure and on changes in the judicial structure (including new judgeships). ${ }^{100}$

The most senior judge in each circuit found himself with greater governance authority within the judiciary, contributing to the development of judicial rules and policy and, outside the judiciary, speaking as a representative of his colleagues. The Council effectively established a principal for each court. Senior judges had taken on informal responsibilities before, but the Act recognized a unique role for them. In addition, the Judiciary Act of 1922 granted the senior circuit judge authority to designate district judges to serve in other districts and circuit judges to sit on district courts. ${ }^{101}$

The Judicial Code of 1948 formalized the senior judge position as the "chief judge" of each circuit and vested administrative authority

97. See William H. Taft, Attacks on the Courts and Legal Procedure, 5 KY. L.J. 3, 14-15, 17 (1916) (reporting his speech delivered in 1914 at the Cincinnati Law School commencement); see also Peter Graham Fish, The Politics of Federal Judicial Administration 30-32 (1973) (describing Taft's judicial reform work based on an examination of published materials, as well as relevant correspondence between Taft and the Attorney General, and the internal Department of Justice memoranda).

98. See William Howard Taft, Possible and Needed Reforms in Administration of Justice in Federal Courts, 8 A.B.A. J. 601, 601-02 (1922).

99. See Judiciary Act of 1922, ch. 306, § 2, 42 Stat. 837, 837-40 (codified as amended at 28 U.S.C. $\$ 331$ (2000 \& Supp. II 2002)) (providing that the Chief Justice call an annual conference of "the senior circuit judge of each judicial circuit"); see also FELIX FRANKFURTER \& JAMES M. LANDIS, THE BUSINESS OF THE SUPREME COURT 227-29 (1928) (describing Taft's judicial reform efforts, particularly regarding court management, and how he achieved most of his reform goals only after he became Chief Justice); Walter F. Murphy, Chief Justice Taft and the Lower Court Bureaucracy: A Study in Judicial Administration, 24 J. POL. 453, 453-59, 475-76 (1962) (analyzing Taft's efforts to create a bureaucratic structure within the judicial branch as a means to improve Supreme Court-lower court relations); Taft, supra note 98 (encouraging members of the American Bar Association to support the act).

100. See Judiciary Act of $1922 \S 2,42$ Stat. at 838 (requiring the conference to "make a comprehensive survey of the condition of business in the courts of the United States" and make any necessary recommendations); see also C.S. Potts, Unification of the Judiciary, A Record of Progress, 2 TEX. L. REV. 445, 448, 458-63 (1924) (describing the activities of the first two meetings of the Federal Judicial Council).

101. See Judiciary Act of $1922 \S \S 3,5,42$ Stat. at 839.40 (amending sections 13 and 18 of the existing Judicial Code). 
in the position. ${ }^{102}$ The new title was created in "recognition of the great increase in administrative duties of [senior] judge[s]."103 Following the Judicial Council's format, the Act included a system of selection based on age and experience: "The circuit judge senior in commission shall be the chief judge of the circuit." 104 Shortly after passage, Third Circuit Judge Albert Maris applauded the creation of an "administrative head" of each court, which would allow the individual courts greater control over judicial business. ${ }^{105}$ Unlike the former automatic and mandatory nature of the "senior judge" position, the chief judge position was voluntary. A judge could opt not to be chief and continue to serve as an active circuit judge. ${ }^{106}$

The rules for succession have changed twice since 1948 (see Table 1). Originally a chief judge could serve as long as the judge wished. ${ }^{107}$ In 1958, Congress imposed a mandatory age limit for chiefs (though not for judges) of seventy after expressions of concern about judges continuing to govern courts after they had lost the mental capacity to do so. ${ }^{108}$ A more dramatic change was instituted in 1982, altering both the term and selection of chief judges. ${ }^{109}$ Chief judges

102. See Judicial Code of 1948 , ch. $646, \S \S 45,136,62$ Stat. 869,871 (codified as amended at 28 U.S.C $\S 45(2000)$ ). The Code also changed the name of federal intermediate appellate courts from "circuit courts of appeals" to "courts of appeals." Id. $\S 43(\mathrm{a}), 62$ Stat. at 870 (codified at 28 U.S.C. $§ 43(a))$.

103. Reviser's Note, H.R. REP. No. 80-308, at A6 (1947).

104. Judicial Code of $1948 \S 45,62$ Stat. at 871 .

105. Albert B. Maris, New Federal Judicial Code: Enactment by 80th Congress a Notable Gain, 34 A.B.A. J. 863, 864-66 (1948) (considering the administrative needs in both district and circuit courts). One district judge believed the 1948 Act merely produced a "change[ of nomenclature of rather minor importance" because the most senior judge became the chief judge. Clarence G. Galston, An Introduction to the New Federal Judicial Code, 8 F.R.D. 201, 202 (1948). Judge Galston is right, up to a point: The statute's only specific command was to change the name of the position. But, as Maris argues, Congress thereby acknowledged the significant evolution in the position's authority between 1922 and 1948.

106. Judicial Code of $1948 \S \S 45,136,62$ Stat. at 871,897 .

107. Id. $\S 136,62$ Stat. at 871 ("If the chief judge desires to be relieved of his duties as chief judge while retaining his active status as circuit judge, he may so certify to the Chief Justice of the United States.").

108. Act of Aug. 6, 1958, Pub. L. No. 85-593, 72 Stat. 497; see S. REP. No. 85-1780 (1958), as reprinted in 1958 U.S.C.C.A.N. 3256, 3257-58, 3260; 1956 ANNUAL REPORT OF THE PROCEEDINGS OF THE JUDICLAL CONFERENCE OF THE UNITED STATES 312.

109. The Senate Report on the Federal Courts Improvement Act of 1982 explained that under the Evarts Act, "a judge who becomes chief judge . . . at age 50 may serve as chief judge for twenty years, while a judge who becomes chief judge at age 69 will serve for only one year." $\mathrm{S}$. REP. No. 97-275, at 25 (1981). Thus, a statutory scheme based "solely on senority, without a minimum or maximum term" might "require the retention for decades of a chief judge who may or may not have the interest or ability to be an enthusiastic administrator" and may also lead to "rapid rotation ... creating instability in the chief administrative office of the court." Id. The Report notes that both had occurred. Id. The purpose of the revision was to solve the former problem through a maximum term of office and to solve the latter by starting a chief judge's term 
who have taken office since 1982 serve either for seven years or until reaching age seventy, whichever occurs first. ${ }^{110}$ The 1982 statute also altered the selection of a successor: when a chief judgeship is vacant, the position passes to the most senior active judge who is no older than sixty-four, has served for at least one year, and has not served previously as chief judge. ${ }^{111}$ While these changes are fairly significant, they do not reflect the wholesale rejection of a seniority system of selection. ${ }^{112}$

Table 1. Serving as Article III Chief Judge

\section{Requirements at Time of Becoming Chief Judge}

\begin{tabular}{llll}
\hline Period & Years & $\begin{array}{l}\text { Maximum Age at } \\
\text { Appointment }\end{array}$ & $\begin{array}{l}\text { Maximum Length } \\
\text { of Service }\end{array}$ \\
\hline 0 & Pre-1948 & no chief judges & \\
1 & $1948-1958^{*}$ & no maximum & no limit \\
2 & $1958-1982^{* \star}$ & 69 & until age 70 \\
3 & $1982-$ present $^{* * *}$ & 64 & $\begin{array}{l}7 \text { years or until age } 70, \\
\text { whichever comes first }\end{array}$ \\
\hline
\end{tabular}

* Judicial Code of 1948, ch. 646, $\S 43,45,136,62$ Stat. 869, 870, 871.

** Act of Aug. 6, 1958, Pub. L. No. 85-593, 72 Stat. 497.

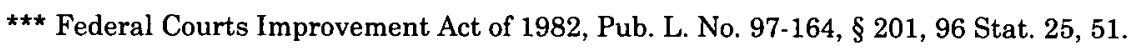

at least six years before she turns the mandatory retirement age of seventy." Id. at 25-26. In 1975, the Hruska Commission on Revision of the Federal Court Appellate System Structure and Internal Procedures recommended the move to a single seven-year term in order "to minimize the impact of a chief judge who lacks administrative abilities, while allowing the chief judges who are good administrators sufficient time to have a beneficent effect on the functioning of their circuits." Hruska Commission, Recommendations for Change, 67 F.R.D. 195, 274 (1975).

110. The mandatory term limit of seven years did not apply to chief judges who took office prior to the Act's October 1, 1982 effective date. Federal Courts Improvement Act of 1982, Pub. L. No. 97-164, § 203, 96 Stat. 51, 53 (1982).

111. 28 U.S.C. $\S 45(a)(1)(2000)$. The statute includes a method of selection when no one satisfies these requirements. The chief judge will be either the youngest circuit judge over sixtyfour who has served for at least one year or, if no judge meets those criteria, the most senior of the active judges who has not served previously as chief judge. Id. $\S 45(\mathrm{a})(2)(\mathrm{A})$-(B). An appointment under these conditions is temporary, lasting until someone fulfills the three core requirements. $I d$. $\S 45(\mathrm{a})(3)(\mathrm{B})$.

112. The Hruska Commission on Revision of the Federal Court Appellate System considered alternatives such as election by peers or selection by a higher court, but rejected both because they would "politicize the selection process." Hruska Commission, supra note 109. 
The voluntary departure options have remained unchanged during the entire period. The statute provides that a chief judge may step down voluntarily by retiring, taking senior status, or informing the Chief Justice. ${ }^{113}$ A chief judge may exercise the third option for any reason and continue as an active judge on the court. Resignation from the court, perhaps to take another position, as when D.C. Circuit Chief Judge Abner Mikva left to become President Bill Clinton's White House Counsel, seems more akin to a voluntary departure than an involuntary one. Impeachment and conviction or death would fall into the involuntary category.

From 1948 through 2006, 125 circuit judges have led their circuit as chief. Nearly all have been white males. While a roughly equal number of Democratic and Republican appointees have served as chief judge since 1948, the relative number during each period reflects the political affiliation of the Presidents who controlled nominations during those years. Table 2 sets forth those and other salient characteristics of the chief judges. ${ }^{114}$

Table 2. Summary Statistics for Chief Judges: Aggregate and by Period

\begin{tabular}{lllll}
\hline & $\begin{array}{l}\text { All Periods } \\
1948-2006\end{array}$ & $\begin{array}{l}\text { Period 1 } \\
1948-1958\end{array}$ & $\begin{array}{l}\text { Period } 2 \\
1958-1982\end{array}$ & $\begin{array}{l}\text { Period } 3 \\
1982-2006\end{array}$ \\
\cline { 2 - 5 } Age Joined the Federal Bench & 46.8 & 48.6 & 48.6 & 44.3 \\
Age Joined the U.S. Court of Appeals & 48.8 & 51.6 & 50.7 & 45.9 \\
Age Became Chief Judge & 62.8 & 68.4 & 62.9 & 60.4 \\
Age Stepped Down as Chief Judge & 68.7 & 74.6 & 68.8 & $65.5^{\star}$ \\
Female & $6.4 \%$ & $0.0 \%$ & $2.0 \%$ & $13.2 \%$ \\
Non-White & $4.8 \%$ & $0.0 \%$ & $3.9 \%$ & $7.5 \%$ \\
Appointed by Democratic President & $52.8 \%$ & $47.6 \%$ & $68.6 \%$ & $39.6 \%$ \\
N & 125 & 21 & 51 & 53 \\
\hline
\end{tabular}

*This figure is based on forty-one chief judges who began and completed their terms during Period 3 and thus excludes the twelve chief judges currently presiding over their respective circuits.

113. See 28 U.S.C. § $45(a)(1)$ (providing that the chief judge must be in "regular active service" and thus neither retired nor senior); $i d . \S 45(\mathrm{c})$ ("If the chief judge desires to be relieved of his duties as chief judge while retaining his active status as circuit judge, he may so certify to the Chief Justice of the United States.").

114. Appendix Table 2A, infra p. 51, depicts these variables by circuit. 


\section{B. The Real and Potential Power of Chief Judges}

Chief judges may influence legal policy in either of two ways: (1) through their participation in cases (a means also available to peers), or (2) through their special formal and informal powers as chiefs. As to the former, the chief judge holds the same vote as her colleagues on a panel but may be able to control the agenda within a case or have greater sway over her colleagues. As to the latter, the chief judge has a wide range of powers that may affect a court in ways small and large. A chief judge may, or may not, choose to exercise those powers to further her personal preferences. But, as we describe below, the potential exists for chiefs to do so, and some evidence demonstrates that they have. Even if they do not exercise their special authority for policy ends, chiefs know their successors might. And they may, therefore, care about the identity of the next chief.

\section{The Chief Judge on a Panel}

The chief judge is only one vote on a panel-whether a threejudge panel or an en banc sitting. But chiefs take precedence over their colleagues, even those who have served longer. They preside over oral arguments and the private case conference. If the chief judge is in the majority, she assigns the majority opinion. ${ }^{115}$ These statutorily granted powers are meaningful. The chief may act as an agendasetter, focusing on particular issues, or characterizations of issues, and excluding others. ${ }^{116}$

The chief also may use her formal status as head of the court to gain support for a particular outcome. In close, difficult, or important cases, a judge may be unsure of her position or may simply change her mind. ${ }^{117}$ Numerous examples exist of judges switching sides or allowing revision of their opinions to satisfy the views of others. ${ }^{118}$

115. See 28 U.S.C. $§ 45(b)$ ("The chief judge shall have precedence and preside at any session of the court which he attends."); see also E. Barrett Prettyman, The Duties of a Circuit Chief Judge, 46 A.B.A. J. 633, 633 (1960) (describing his experience as chief judge of the D.C. Circuit).

116. Based on extensive interviews with circuit judges, J. Woodford Howard concluded that "[h] aving psychological advantages as presiding officers, [chief judges] are expected to lead discussions, clarify issues, and speak for the court in the most controversial cases." HowARD, supra note 32 , at 226 .

117. See, e.g., J. Woodford Howard, Jr., On the Fluidity of Judicial Choice, 62 AM. PoL. SCI. REV. 43 (1968) (presenting evidence that judicial decisions reflect the end of a process that is quite fluid, in which judges shift positions and bargain over outcomes).

118. See, e.g., LINDA J. GREENHOUSE, BECOMING JUSTICE BLACKMUN 33-34 (2005) (discussing then-Eighth Circuit Judge Blackmun's communications with his colleagues in which he offered to eliminate from a death penalty opinion language revealing his personal doubts about the death penalty if they disapproved of the comments). 
Uncertainty provides opportunity and movement reflects motivation; both may be linked to internal bargaining. Chief judges appear particularly well positioned to exercise influence in that setting. Freshman judges are most likely to be unsure about their positions, giving rise to the idea of a "freshman effect." And judges have indicated (and sometimes complained) that chiefs hold particular sway over their newly appointed brethren. ${ }^{119}$

\section{Formal Authority}

The Federal Judicial Center observed in its official manual for chief judges that chiefs "do not operate under an explicit grant of administrative authority."120 Nevertheless, everyone agrees that final responsibility for court functions lies with the chief judge. "That consensus in turn provides chief judges a sizable reservoir of authority." 121 The responsibilities may be related closely to cases or seem wholly unrelated. But all of the chief's authority affects her colleagues and thus the court. The chief's leadership "is best understood in terms of [her] influence" on her colleagues. The chief "influences [a colleague] to do $x$ to the extent that [the chief] performs some activity $y$ as a result of which [the colleague] chooses to do $x$."122 The import of a chief's actions, then, may turn on the ways in which those actions affect the actions of other judges.

Chief judges oversee and manage a range of activities that may affect the development of law and policy. For example, chief judges decide how to divide cases by type, granting certain kinds of cases greater attention and benefiting certain parties over others. ${ }^{123}$ If an indigent defendant's court-appointed attorney requests additional pay or other monetary assistance on appeal, the chief judge decides whether the case merits it, ${ }^{124}$ affecting criminal defense in the instant case, but also the actions of criminal defense attorneys in future cases in that court. Chiefs also handle judicial conduct and disability

119. See Papers of Justice Harry Blackmun, Library of Congress, Box 12, Folder 13 [hereinafter Blackmun Papers]. Warren Burger, then sitting on the D.C. Circuit, complained to his friend Harry Blackmun that new judges were too under the sway of the chief, someone with whom Burger sharply disagreed. Id.

120. ChIEF CiRcUit JuDGES' DeskBOOK, supra note 83, at 6 \& n.23.

121. Id. at 6.

122. Danelski, supra note 75, at 506-07 (explaining how the Chief Justice's influence over associate Justices on the Supreme Court works).

123. For example, a chief may decide to assign certain types of cases for initial review by a staff attorney. CHIEF CIRCUIT JUDGE'S DESKBOOK, supra note 83.

124. Criminal Justice Act, 18 U.S.C. $\S 3006 A(d)(3)$, (e)(3) (2000 \& Supp. IV 2004). 
complaints. ${ }^{125}$ And, as we saw in Grutter, chiefs circulate petitions for en banc hearing and may append to those petitions their own views on the merits of the petitions. ${ }^{126}$

Chief judges also exercise power through their participation in court-related bodies. They serve on or convene national and circuit judicial organizations. ${ }^{127}$ The U.S. Judicial Conference, on which all chief judges serve, has proposed significant changes in habeas and other rules of civil procedure. Chief judges may appoint special internal committees to study issues of concern. For example, Chief Judge Wald, only the second woman to serve as chief judge, created a committee to study gender and racial bias on the D.C. Circuit. ${ }^{128}$

A chief judge's most potent tool is selecting decisionmakers for cases. Chiefs may affect the identity of arbiters in several ways. They have formal authority with respect to the process of assigning judges to cases. While that power is often limited by formal or informal rules regarding selection of active judges for panels, the authority to invite "visiting" judges (i.e., district and circuit judges from another court) or to designate district judges to sit with the circuit is largely unfettered. The circuit chief also selects the judges who sit on special three-judge district courts, authorized by Congress to hear highly political disputes like voting rights and civil rights cases. ${ }^{129}$

125. 28 U.S.C. $§ \S 351-52$ (2000 \& Supp. II 2002) (providing that all complaints received regarding a judge's conduct be promptly transmitted to the chief judge and that the chief judge determine the course of action to take); $i d$. $§ 372$ (a)-(c) (requiring that any district or circuit judge who desires to retire from active service as a result of permanent disability affecting his capacity to perform his duties must submit to the President a certificate of disability signed by the chief judge of his circuit). Furthermore, as part of ethics rules, the Regulations of the Judicial Conference require judges to obtain chief circuit judge approval for any compensated teaching. Regulations of the Judicial Conference of the United States under Title VI of the Ethics Reform Act of 1989 Concerning Outside Earned Income, Honoraria, and Outside Employment $\S 5$ (d)(3) (Aug. 15, 1990), available at http://www.uscourts.gov/ibrary/conduct_outsideemployment.html.

126. For an example of such a communication, see Blackmun Papers, supra note 119, at Box 38, Folder 16, Case File 571. Eighth Circuit Chief Judge Vogel included with a motion for en banc hearing a cover letter to his colleagues subtly encouraging en banc review. One judge in a subsequent letter to his colleagues questioned the merits of a full court hearing but nevertheless stated he would defer to "you as Chief judge to handle this as you think best." Id.

127. See 28 U.S.C. $\S 331$ (providing that the Chief Justice shall summon the chief judge of each circuit to be a member of the U.S. Judicial Conference); $i d$. $\S 332$ (providing that at least twice a year, the chief judge of each circuit shall call and lead a judicial council of circuit and district judges within that circuit); $i d . \S 333$ (2000) (providing that the chief judge of each circuit may call and run circuit judicial conferences that include district judges as well as invited members of the bar); id. $\S 474(\mathrm{a})$ (providing that the chief circuit judge and chief district judges of each circuit shall meet to discuss civil justice expense and delay reduction plans under the Civil Justice Reform Act of 1990).

128. Wald, supra note 91 , at 1127 n.2.

129. Congress dictates when three-judge district courts, comprised of one circuit and two district judges, will be used instead of a single district judge. See 28 U.S.C. $\$ 2284$ (providing that 
Judges, like Sixth Circuit Judge Boggs in Grutter, have accused their chiefs of using assignment power to affect the outcome in a specific case or class of cases. The most prominent example involves Fifth Circuit civil rights cases in the 1960s. During the tense postBrown period, the lower courts in the Fifth Circuit were responsible for carrying out the Supreme Court's desegregation decree in the Deep South. ${ }^{130}$ In 1963, a segregationist circuit judge accused then-Chief Judge Elbert Tuttle of manipulating panel assignments to ensure that progressive judges, who were a minority of the circuit, controlled the outcome in civil rights lawsuits. ${ }^{131}$ Political scientists Burton Atkins and William Zavoina assessed the probability that Fifth Circuit panel assignments from 1961 to 1963 were random as claimed by Tuttle. ${ }^{132}$ They found that a grossly disproportionate number of race relations cases were heard by the four pro-civil rights judges, including Chief Judge Tuttle. ${ }^{133}$

a three-judge panel "shall be convened when otherwise required by Act of Congress, or when an action is filed challenging the constitutionality of the apportionment" of a congressional or state voting district). Parties in such disputes appeal directly to the Supreme Court, bypassing the court of appeals. Id. $\S 1253$. After a period of popularity, three-judge district panels are now required infrequently, but continue to decide timely voting rights and civil rights case. See id. $\S$ 2284. The highly anticipated Texas redistricting case, arising from Tom Delay's 2003 efforts to ensure Republican control of state legislative offices for the foreseeable future, was first heard by a three-judge district court that included Fifth Circuit Judge Patrick Higginbotham and District Judges Lee Rosenthal and T. John Ward. Henderson v. Perry, 399 F. Supp. 2d 756, 758 (E.D. Tex. 2005). The Supreme Court largely upheld their ruling. League of United Latin Am. Citizens v. Perry, 126 S. Ct. 2594 (2006).

130. See generally J. W. Peltason, Fifty-Eight Lonely Men: Southern Federal Judges AND SCHOOL DESEGREGATION (1962) (explaining how, in the years following the Brown II decision, the local battles over its implementation took place largely in Fifth Circuit courtrooms).

131. See Armstrong v. Bd. of Educ., 323 F.2d 333, 352-61 (Cameron, J., dissenting from denial of rehearing en banc). Cameron accused Chief Judge Elbert P. Tuttle of "gerrymandering" circuit panels and three-judge district panels to ensure that they were dominated by "The Four," referring to the pro-civil rights judges: Chief Judge Tuttle and Judges Richard T. Rives, John Minor Wisdom, and John R. Brown. Id. at 353 n.1, 359. Cameron wrote, "The idea that the Chief Judge may thus gerrymander the United States Judges of a State in order to accomplish a desired result is, I think, entirely foreign to any just concept of the proper functioning of the judicial process." Id. at 359.

132. Tuttle only gained the chief position (and case-assignment authority) because Judge Rives, who became chief judge in 1959, stepped down after less than a year in order to allow Judge Tuttle to take over circuit leadership. See FRANK T. READ \& LUCY S. MCGoUGH, LET THEM BE JUdged: THE JUdICIAL INTEGRATION OF THE DEEP SOUTH 183 (1978) (explaining that Judge Rives's resignation was timed so that Tuttle would become chief judge, and quoting a statement by Judge Rives that Tuttle "was an ideal man to be chief judge" and had "much administrative ability" (internal quotations omitted)); JOHN M. SPIVACK, RACE, CIVIL RIGHTS AND THE UNITED STATES COURT OF APPEALS FOR THE FIFTH JUDICLAL CIRCUIT 126-27 (1990) (describing the autocratic rule of Hutcheson, who "ran his court with strict discipline").

133. Burton M. Atkins \& William Zavoina, Judicial Leadership on the Court of Appeals: A Probability Analysis of Panel Assignment in Race Relations Cases on the Fifth Circuit, 18 AM. J. 
Manipulation of case assignments, however, is likely rare. ${ }^{134}$ Neither the Due Process Clause nor the Equal Protection Clause of the U.S. Constitution nor the statute creating lower federal courts appears to require the random assignment of judges. ${ }^{135}$ However, most courts have instituted procedures that result in roughly random assignment of judges to cases. And some courts have promulgated local rules mandating random assignment with the usual constraints dictated by the location of oral arguments and availability of judges. ${ }^{136}$ Those constraints, of course, may be affected by the chief judge. For example, court rules do not dictate the means of selecting designated district or visiting circuit judges to include in the pool of available judges; they leave it to the chief's discretion. ${ }^{137}$ In addition, the chief often may adjust the location of oral arguments. ${ }^{138}$ In the end, chief judges who are so inclined can find ways to affect assignments.

POL. SCI. 701, 709 (1974) (finding that the pro-desegregation judges heard civil rights cases "at a frequency significantly above that which would be expected by chance").

134. Of course, a policy of random assignments does not mean assignments are, in fact, random or that people will not contend that they are not. Despite the Seventh Circuit's official policy of random assignments, lawyers have complained that panel assignments are non. random. "The Chicago Council of Lawyers, a "public interest bar association," investigated these concerns and failed to find systematic evidence to support the accusations. Chicago Council of Lawyers, Evaluation of the United States Court of Appeals for the Seventh Circuit, 43 DEPAUL L. REV. 673, 705-06 (1994) ("For a long time, many members of the bar have expressed concern that assignments to panels are not in fact random. All the evidence that the council has seen is to the contrary, however, and the Council is convinced that the official policy is followed.").

135. See, e.g., United States v. Claiborne, 870 F.2d 1463, 1467 (9th Cir. 1989) (holding that random assignment of judges is not constitutionally required); United States v. Edwards, $39 \mathrm{~F}$. Supp. 2d 692, 707 (M.D. La. 1999) ("It is also well-settled that a defendant does not have the right to have his case heard by a particular judge. Nor does a defendant have the right to have his judge selected by a random draw." (footnotes omitted)); United States v. Keane, 375 F. Supp. 1201, 1204 (N.D. Ill. 1974), aff'd in part, rev'd in part on other grounds, 522 F.2d 534 (7th Cir. 1975) ("[D]ue process does not accord [the defendant] a right to have a judge assigned to his case on a random basis.").

136. See, e.g., First Circuit Court of APPEals, InTernal Operating Procedures $\S \mathrm{D}$ (2006) (providing that "cases are assigned to panels on a random basis provided, however, that a case may be assigned to a particular panel or to a panel including a particular judge" when circumstances such as availability of judges or scheduling changes so require); see also Brown \& Lee, supra note 86, at 1041-42 ("[While] all federal circuits purport to rely on the random assignments of judges to panels ... substantial amounts of discretion erode the randomness of those systems." (footnotes omitted)).

137. See, e.g., United States v. Claiborne, 870 F.2d 1463, 1466 (9th Cir. 1989) ("[U]nder both [28 U.S.C.] $\S 291(a)$ and $\S 46(b)$, the chief judge retains a great deal of discretion in deciding when out-of-circuit judges are needed.").

138. For example, the Fourth Circuit, where George clerked during the 1992-93 term, had developed a practice of holding simultaneous summer sessions in various locations throughout the five states in this mid-Atlantic circuit. This allowed the court to have contact with various parts of the circuit and also allowed some judges to sit closer to home. In the 1980s and 1990s, one such location was Wilmington, North Carolina, where Judge Samuel J. Ervin III had a beach home. Judges Francis D. Murnaghan, Jr., James M. Sprouse, and J. Dickson Phillips, Jr. sat 
Chief judges must be cautious if they use such highly visible techniques to affect case outcomes. Disgruntled colleagues, like those in Grutter and the Fifth Circuit civil rights cases, may blow the whistle. Former Chief Judge Wald contended that "the line between administration and substance must be kept scrupulously clear and clean. The majority of the court must have no reason to suspect that the Chief's substantive views of circuit law development in any way influence the way in which the court is managed." 139 While Judge Wald was arguing that it is inappropriate to use the chief judge's administrative power to influence outcomes, she acknowledged that it is possible. Indeed, a chief judge may resign strategically, not to gain a successor with the same attitude, but to avoid an ideologically opposed successor who might be willing to use administrative authority to affect policy.

\section{Informal Powers}

A chief judge's informal powers are more extensive than her formal powers, and they allow for the more subtle exercise of influence. Informal powers include problem solving, developing and enforcing codes of conduct, and the "dissemination of information within and about the circuit." 140 As with any organization, control of these conduits allows a leader to set agendas, encourage certain actions, discourage other actions, and increase the likelihood that a court's limited resources are used for issues of greatest concern to the leader. ${ }^{141}$

Chief judges also handle small requests that affect daily life for their colleagues. For example, they control whose turn it is for a new computer, the renovation and assignment of office space, or the hiring

with Judge Ervin in Wilmington. All four judges were appointed by President Carter. By 1996, when Ervin's chief judgeship ended, the majority of Fourth Circuit active judges were Republican appointees. The new chief judge J. Harvie Wilkinson III soon ended the simultaneous sessions and with it the certainty of one all-liberal panel in July in Wilmington. Cf. Neil A. Lewis, A Court Becomes a Model of Conservative Pursuits, N.Y. TIMES, May 24, 1999, at A1 (discussing the Fourth Circuit's movement to "become the boldest conservative court in the nation" since Wilkinson became chief judge).

139. Wald, supra note 91 , at 1129 .

140. CHIEF CIRCUIT JUDGES' DESKBOOK, supra note 83, at 11-27.

141. As J. Woodford Howard, Jr. observed in his careful study of three circuits:

Policy leadership, that is, influence in deciding cases and developing legal doctrine, is officially divorced from administration.... The trouble is that the attempted divorce of administration from policy making seldom succeeds in most organizations. Merely to recite the managerial tasks of chief judges is to cast doubt on the distinction in Courts of Appeals as well.

HOWARD, supra note 32 , at 225-26. 
of personnel. The chief judge prepares the agenda, circulates information for court council meetings, and presides over those meetings. The court council, in turn, holds most of the formal authority to manage the court: selecting staff, approving courtrooms and chambers, and the like. The chief judge's power with respect to the council means that she can influence the outcomes in such instances. For example, the chief judge takes stock of building needs and raises issues with the council and/or Administrative Office.

The chief is the court's representative to external organizations, including other courts, legislatures, the bar, law schools, and the press. ${ }^{142} \mathrm{~A}$ chief judge has special authority when speaking on issues such as the creation of new judgeships or courts, the expansion or contraction of federal jurisdiction, and the treatment of other issues that affect the power and decisions of the federal judiciary. ${ }^{143}$

The chief may also affect the internal dynamics of a court. As then-Chief Judge E. Barrett Prettyman of the D.C. Circuit explained, "[T] he Chief Judge is by the bare fact of his office in a place of peculiar obligation in respect to ... intangible attributes... [that] come to characterize" the circuit, such as its cohesiveness, effectiveness, and collegiality. ${ }^{144}$ Intracourt relationships may dictate the willingness of judges to dissent on panels, to vote for en banc review of colleagues' decisions, or to defer in other ways to the actions of their peers. ${ }^{145}$ Every time a judge speaks out in a dissent, it sends a signal to a litigant considering an appeal, a Justice deciding on certiorari, and a trial judge wondering about the strength and meaning of a particular circuit precedent.

The chief judge position can wield meaningful influence on policy within a court. Whether a chief uses her power to achieve policy goals will depend on personality and ability, as well as the position.

142. ChIEF CiRCUIT JUDGES' DeSKBOOK, supra note 83, at 16-17.

143. Chief judges frequently make speeches and publish articles on such subjects. See, e.g., Proctor Hug, Jr. \& Carl Tobias, A Preferable Approach for the Ninth Circuit, 88 CAL. L. REV. 1657 (2000) (critically evaluating two official Ninth Circuit reorganization plans under consideration by Congress); Lumbard, supra note 48, at 31.41 (offering his views on a range of initiatives to reduce federal caseloads, including curtailing jurisdiction, creating two-judge circuit panels and specialized courts of appeal, increasing summary dispositions, imposing penalties for frivolous appeals, and implementing staff increases).

144. Prettyman, supra note 115.

145. See, e.g., Jason J. Czarnezki \& William K. Ford, An Empirical Analysis of Dissensus on the United States Courts of Appeals 10, 16-17 (Marquette Univ. Law Sch. Legal Studies, Working Paper No. 06-31, 2007), available at http://ssrn.com/abstract=914409 (remarking on the assumption that "the chief administrator of a circuit may play an important role in promoting agreement on the court," but finding little statistical evidence that the length of a chief judge's tenure is associated with higher rates of agreement). 
But judges and others have believed that at least some chief judges have used their position to gain influence. As a D.C. Circuit judge, Warren Burger reportedly "watched enviously as [David L.] Bazelon used his position as Chief Judge to serve his own philosophy."146 Burger vowed that when he assumed the Chief Justiceship, Bazelon would be his "model" for serving as chief even though Burger rarely followed Bazelon's lead on any subject while they served together on the court of appeals. ${ }^{147}$

\section{A STRATEgIC DePARTURE THEORY OF CHIEF JUDGE TENURE}

Chief circuit judges are chosen based on tenure and age. Selection based on seniority is unusual for courts. The leadership of the U.S. Supreme Court and state high courts is based on either appointment by the executive or election by one's colleagues. ${ }^{148}$ Former D.C. Circuit Chief Judge Patricia Wald has argued that the seniority selection system avoids the "political coloration" resulting from appointment battles in the appointment system and internal politicking in the election one. ${ }^{149}$ But does it?

Chief judges can time their departure to ensure a successor who shares the chief's ideological views. This strategic departure hypothesis is consistent with the theory that judges time their retirements from the bench to coincide with the term of a President of the same party. But existing studies of judicial tenure are mixed: some describe a world of strategic retirements while others point to the significance of non-policy factors such as age and pension. ${ }^{150}$ Even

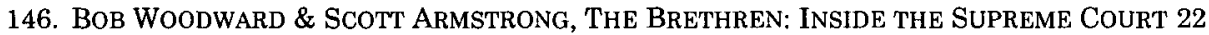
(paperback ed. 2005) ("As spokesman for the Court of Appeals, as its senior judge and chief administrator, Bazelon was able to assign extra law clerks, and control the office space, supplies and accouterments that make working conditions a pleasure or an annoyance. His influence with his colleagues, and especially the new judges, was legendary.").

147. Id.; see also GreEnHouse, supra note 118, at 24 (describing Bazelon as Burger's ideological "nemesis").

148. For information on state supreme courts, see National Center for State Courts, State Court Structure Charts, http://www.ncsconline.org/D_Research/Ct_Struct/Index.html (last visited Dec. 27, 2007).

149. See Wald, supra note 91, at 1128 (reasoning that "[p]opular election by one's colleagues, or even appointment by the President, could add a disruptive element of competitiveness or even a political coloration to the job" and that therefore "[s]eniority probably does work best").

150. Compare Barrow \& Zuk, supra note 66, at 466-67 (concluding that the political affiliation of the President had a small but statistically significant effect on judicial turnover), and David C. Nixon \& J. David Haskin, Judicial Retirement Strategies: The Judge's Role in Influencing Party Control of the Appellate Courts, 28 AM. POL. Q. 458, 458 (2000) (arguing that "[t]he only important strategic political consideration... is whether a judge contemplating retirement faces an opposing party president and how far off that president's next election is"), with Yoon, supra note 58, at 177 (concluding that judicial pensions are the primary explanation 
those finding that judges are influenced by the identity of the current President report a relatively small effect. ${ }^{151}$ This may reflect the uncertainty faced by judges who wish to retire strategically. ${ }^{152}$ If the sitting President does not match the judge's preferences, the judge delays retirement in hopes that a more appealing President will win election-a high-risk prospect. Even if the sitting President matches the judge's preferences, the selection process itself is highly political and may produce a less-than-satisfactory replacement. Moreover, the voting behavior of that replacement will be revealed only over time.

A chief judge faces a very different context when deciding whether to remain chief. The identity of a chief judge's replacement is (nearly) certain because the line of succession is set by statute. Furthermore, the chief judge would be very familiar with the voting behavior of the person who stands next in line. If a judge is uncertain about her replacement, then the best decision may be to remain in office. When a chief judge can be reasonably confident about the consequences of leaving the position early, she should act to protect her interests. Hence, if the attitudinal theory accurately accounts for appellate judge behavior, we would be more likely to see evidence of ideological motivations in decisions regarding chief judge tenure than those concerning judicial tenure. A strategic theory of departure, built on attitudinal assumptions, produces a number of hypotheses:

Hypothesis 1: A chief judge will serve her entire term.

A chief judge will prefer to serve an entire term because it is the best way to ensure the protection or development of her preferences. The simplest attitudinal prediction, then, is full tenure. Of course, other explanations could drive the completion of one's term: a sense of obligation to the institution, pleasure derived from holding a position of special authority, or hunger for power. Thus, support for this hypothesis, standing alone, will not resolve the attitudinal question.

for judicial vacancies and that political factors appear to be nonsignificant). See also Spriggs \& Wahlbeck, supra note 66, at 578-79 (finding that pensions as well as political environment influenced judicial turnover).

151. See, e.g., Barrow \& Zuk, supra note 66, at 466-67.

152. See Yoon, supra note 67, at $1051 \mathrm{n} .77$ (positing that Democrat-appointed judges hoping for a successor of the same political affiliation may have remained longer on the bench in order to wait for a change in political affiliation in the Republican-dominated White House). 
Hypothesis 2: A chief judge will not step down until close to the end of her term.

A chief judge will prefer to serve as much of her term as possible because she is most confident about her policy positions and willingness to use the office to further those goals. Thus, a rational judge will defer stepping down until as late as possible to ensure a replacement that is most likely to protect her interests. Those interests may include the use of the chief post to affect outcomes or the protection of the chief post from political uses.

Given some uncertainty about the tenure of colleagues and presidential and senatorial elections that would affect new judges, a chief will not consider leaving early for policy reasons until close to the end of her term. This effect may vary by period. For those who became chief after 1982 (Period 3), terms never exceed seven years. We would expect them to be more likely to step down after completing at least half of the term. ${ }^{153}$ For those who became chiefs between 1958 and 1982 (Period 2), their terms can last for as long as thirty-one years (in the case of one judge who became chief at age thirty-nine). Although a Period 2 term officially ends at age seventy, Period 2 chiefs may view the term as ending earlier, depending on when they started. We expect that Period 2 chiefs will serve a lower percentage of their term than Period 3 chiefs, but that Period 2 chiefs will serve a higher absolute number of years.

A term also may end by death. We expect that chief judges will be more likely to step aside as they grow older because their ability to control the timing of their departure declines as death becomes more probable. Aging also may make the additional work of the chief judgeship more difficult. Thus, older chiefs may be more likely to step down than younger chiefs for both political and non-political reasons.

Hypothesis 3: A chief judge will be more likely to step down early if her replacement has the same ideology or policy preferences.

A rational judge will take the course of action likely to increase the probability that the court will follow her policy preferences. If the chief does not serve her entire term, she should leave voluntarily only if the person who will take over her seat holds the same or similar policy views. We need a measure that will approximate the policy preferences for each judge. Numerous studies have found that the

153. For judges who are exactly sixty-three or younger, the midpoint is three and a half years. For judges who are between sixty-three and sixty-five, the midpoint ranges from 3.5 to 2.5 years. 
party of a judge's appointment President is a good proxy for policy preferences; in other words, judges appointed by Presidents from the same party are more likely to agree with one another than are those appointed by Presidents of different parties. ${ }^{154}$ Thus, we would expect a Democratic appointee to depart early from the chief judgeship only if the successor is a Democratic appointee, and a Republican appointee to depart early only if the successor is a Republican appointee. ${ }^{155} \mathrm{~A}$ more recent and innovative measure of judicial policy preferences is the Judicial Common Space ("JCS") score. ${ }^{156}$ The JCS score is more refined than the appointing President's party measure. If a judge is appointed from a state where one senator (or both senators) is a member of the President's party, then the judge receives that senator's vote-based ideology score (or if both senators are of the same party, an average of their scores). ${ }^{157}$ If neither home-state senator is a member of the President's party, then the judge receives the score for the President. ${ }^{158}$ Because the party measure is better established, we

154. See generally Pinello, supra note 44 (offering an extensive analysis of the use of party affiliations of judges and party of the appointing President as proxies for judicial ideology, and confirming that both are dependable measures of it).

155. Because most judges, in contrast to elected policymakers, have not disclosed their policy preferences publicly, a proxy for attitudes is necessary. Attitudinal studies have demonstrated that the ideological direction ("liberal" or "conservative") of the party of a judge's appointing President is a strong predictor of the case votes of Justices on the Supreme Court and judges on Courts of Appeals. See, e.g., George, supra note 16, at 1678-86 (discussing studies that report these findings and also demonstrating that the majority of Fourth Circuit judges participating in en banc cases between 1962 and 1996 voted their sincere policy preferences as measured by the party of their appointing President).

156. See generally Micheal W. Giles, Virginia A. Hettinger \& Todd C. Peppers, Measuring the Preferences of Federal Judges: Alternatives to Party of the Appointing President (June 11, 2002) (unpublished manuscript, on file with author) (creating and defining the common space measure); Lee Epstein, Andrew D. Martin, Jeffrey A. Segal \& Chad Westerland, The Judicial Common Space, 23 J.L. ECON. \& ORG. 303 (2007) (refining and expanding the measure). See also Micheal W. Giles, Virginia A. Hettinger \& Todd Peppers, Picking Federal Judges: A Note on Policy and Partisan Selection Agendas, 54 POL. RES. Q. 623 (2001) (employing judicial decisionmaking in the U.S. Courts of Appeals as a window through which to reexamine the politics of selection to the lower courts).

157. This vote-based ideology score for senators is known as the NOMINATE score and is widely used in Congressional research. See KEITH T. POOLE \& HOWARD ROSENTHAL, IDEOLOGY AND CONGRESS 295-311 (2d rev. ed. 2007) (providing examples of various applications of the NOMINATE score); see also KEITH T. POOLE \& HOWARD ROSENTHAL, CONGRESS: A POLITICALECONOMIC HISTORY OF ROLL CALL VOTING 233-51 app.A (1997) (explaining and testing the NOMINATE measure of the preferences of members of Congress). The NOMINATE data and related information are available at Keith T. Poole's Voteview website, http://voteview.com/ default.htm (last visited Dec. 27, 2007).

158. The ideological preferences in some instances may be subtle within a given party. For example, on January 24, 2008, Chief Judge Douglas H. Ginsburg announced that he would step down effective February 10, 2008, before the expiration of his term on July 15, 2008. See Press Release, supra note 29. 
report the party measure results in the text and the JCS results in the appendix.

Hypothesis 4: A chief judge will be more likely to step down early if she is in the circuit's ideological majority than if she is in the minority.

A chief judge has greater potential power when she is a member of the party in control of the court. Studies of lower courts have found that judges are more likely to perceive their chief as using her authority for policy ends when she has the support of a plurality of colleagues. ${ }^{159}$ And systematic studies of the Supreme Court have revealed that the Chief Justice's ability to use tools like opinion assignment to achieve ideological goals depends on institutional support. ${ }^{160}$ We thus infer that an incumbent chief judge from the minority party might be less likely to step down voluntarily if the new chief is from the majority party. The majority party's power could be expanded by the additional position of authority. By contrast, a majority party chief will be less sensitive to the identity of a replacement because a minority chief's power is severely limited by numbers.

Hypothesis 5: A chief judge will be more likely to depart for strategic reasons if her departure is not due to retirement or senior status.

A chief judge's decision to step down voluntarily will be related to the reasons for leaving the chief judgeship. That is, a chief judge who steps down because she is retiring will be influenced by factors related to retirement, while a chief judge who steps down but returns

Ginsburg's decision means that the next chief judge will be Judge David B. Sentelle, rather than Judge Karen L. Henderson. Had Ginsburg completed his remaining months as chief judge, Sentelle would have turned 65 during that time and therefore would have been been ineligible to become chief judge. Both Ginsburg and Sentelle were appointed by President Ronald Reagan, in 1986 and 1987 respectively, and both have JCS scores of 0.567 . Judge Henderson was appointed by President George H.W. Bush in 1990 and has a JCS score of 0.410 . Ginsburg's early departure is after the end of our data; thus, it is not included in our statistical analyses. Its inclusion, however, would not have resulted in statistically significant results for the JCS measure in our multivariate model.

159. See HOWARD, supra note 32 , at 228 ("Whether [interviewed] members [of a specific court] agree on 'strategic premises' has much to do with the influence of chief judges on legal policy. For example, Simon E. Sobeloff, the able chief judge of the 4th circuit, lacked majority support for vigorous desegregation which Elbert P. Tuttle enjoyed in the 5th." (citation omitted)).

160. See, e.g., Maltzman, SpRIgGS \& WaHLBECK, supra note 63, at 52-55 ("[J]ustices' decisions result from the pursuit of their policy preferences within constraints that stem from the collegial nature of the institution."). 
to active service will not be influenced by those factors. ${ }^{161}$ Thus, we expect strategic factors to play a greater role for chiefs who return to active service than for those who leave.

Hypothesis 6: A chief judge who is a woman or a minority will be less affected by attitudinal factors than white male chief judges.

We hypothesize that race and gender may play an independent role in chief judge tenure, but we are unsure of the direction of the effect. Few women and people of color have served as chief circuit judges. ${ }^{162}$ They must be unusually ambitious and tenacious to achieve the rare success of a circuit appointment, even more rare given their race or gender. Thus, we would expect them to hold onto a chief judgeship as long as possible. But their race or gender may make it more difficult to serve as chief due to demands unique to their backgrounds. Accordingly, we expect that gender and race may moderate attitudinal effects.

\section{EMPIRICAL ANALYSIS}

We seek to test the foregoing hypotheses against a database we constructed that includes all chief circuit judges. ${ }^{163}$ Our data is drawn, in part, from the Federal Judicial Center ("FJC") database on every Article III judge that has served. ${ }^{164}$ The FJC database contains certain biographical and demographic information on each judge. We supplemented the FJC data with additional variables necessary to our study. ${ }^{165}$

161. See Albert H. Yoon, As You Like It: Senior Federal Judges and the Political Economy of Judicial Tenure, 2 J. EMPIRICAL LEGAL STUD. 495, 509-10, 545 (2005) (reporting a relationship between pension eligibility and retirement from active status).

162. The 125 chief judges who served from 1948 through 2006 include eight white women, five African-American men, and one Hispanic man. By comparison, sixty women, thirty AfricanAmericans, and fifteen Hispanics have served as circuit judges. See the Federal Judicial Center database, supra note 10 , for a biographical directory of all federal judges who have served since 1789 .

163. A complete list of all chief circuit judges through 2006 is included as Table 6 in the Appendix. See infra pp. 56-61.

164. See Federal Judicial Center, supra note 10. We do not include Period 1 chief judges in our multivariate analysis because term limits were not yet in place.

165. For example, the FJC records the first and last year of service, but does not record the specific date on which service began or ended. Thus, a judge who became chief on January 1 , 2006 would have the same starting year as a judge who became chief on December 31, 2006. This simplification makes it difficult to determine whether a judge completed her full term and to tie the timing of departure to time-sensitive variables like court composition. To fill this gap and others, we relied on multiple sources. The Sixth Circuit reports on its exceptional website specific starting dates for all chief judges in the history of the Sixth Circuit courts. See History of the 


\section{A. The Findings}

The first striking finding is that, contrary to Hypothesis 1, chief judges are unlikely to complete their entire term. From 1948 to 2006 , nearly $80 \%$ of chief judges voluntarily left the position before the end of their term. As reflected in Table 3, nearly all returned to active service (eighty-four out of eighty-eight). ${ }^{166}$ Hence, nearly all of the judges could have departed for strategic-rather than economic or health-reasons (Hypothesis 5). Women and minorities were less likely than white men to step down early. More than $90 \%$ of women and $50 \%$ of minorities completed their terms as chief judge (Hypothesis 6).

Focusing on the separate periods reveals that judges who became chief between 1982 and 2006 were slightly more likely than earlier chiefs to step down voluntarily. Of those judges who did not leave voluntarily, all but three completed their terms; two of the Period 1 chief judges died in office, while one Period 3 chief, Stephen Breyer, was promoted out of his post.

Table 3. Reasons for Leaving Chief Judgeship*

\begin{tabular}{|c|c|c|c|c|c|c|c|c|}
\hline \multirow[b]{2}{*}{ Completed Full Term** } & \multicolumn{2}{|c|}{$\begin{array}{l}\text { Period } 1 \\
1948-1958 \\
\end{array}$} & \multicolumn{2}{|c|}{$\begin{array}{l}\text { Period } 2 \\
1958-1982 \\
\end{array}$} & \multicolumn{2}{|c|}{$\begin{array}{l}\text { Period } 3 \\
1982-2006\end{array}$} & \multicolumn{2}{|c|}{$\begin{array}{l}\text { Overall } \\
1948-2006 \\
\end{array}$} \\
\hline & 0 & & 15 & $29.4 \%$ & 7 & $17.1 \%$ & 22 & $19.5 \%$ \\
\hline Elevated to Supreme & 0 & & 0 & & 1 & $2.4 \%$ & 1 & $0.9 \%$ \\
\hline \multicolumn{9}{|l|}{ Court ${ }^{\star \star}$} \\
\hline Died While Chief Judge** & 2 & $9.5 \%$ & 0 & & 0 & & 2 & $1.8 \%$ \\
\hline Returned to Active Service & 19 & $90.5 \%$ & 35 & $68.6 \%$ & 30 & $73.2 \%$ & 84 & $74.3 \%$ \\
\hline $\begin{array}{l}\text { Resigned from Federal } \\
\text { Bench }\end{array}$ & 0 & & 1 & $2 \%$ & 3 & $7.3 \%$ & 4 & $3.5 \%$ \\
\hline Total & 21 & & 51 & & 41 & & 113 & \\
\hline $\begin{array}{l}\text { * A chief judge is assigned to th } \\
\text { for that period would dictate he } \\
\text { here. } \\
\star \star \text { The first three categories are }\end{array}$ & 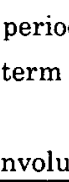 & mit). T & twel & activ & & $\begin{array}{l}\text { dgeship } \\
\text { lges are }\end{array}$ & $\begin{array}{l}\text { s the } \\
\text { ot inc }\end{array}$ & $\begin{array}{l}\text { atute } \\
\text { ded }\end{array}$ \\
\hline
\end{tabular}

Sixth Circuit, Judges Index, http://www.ca6.uscourts.gov/lib_hist/jdge-indexA-D.html (last visited Dec. 28, 2007). A 1970 FJC publication included specific dates for chief circuit judges up to that date, as do biographies of some individual chief judges. For the hundreds of remaining judges, we relied upon Janet Hirt of the Vanderbilt Law Library. Ms. Hirt contacted each court clerk's office directly, requesting the information. We are deeply indebted to Ms. Hirt as well as the individual federal court staff members who assisted us.

166. We treated a judge as stepping down due to senior status if she took senior status within one month after stepping down from the chief judge position. 
Given that chief judges leave their posts voluntarily, are they waiting until late in their terms to depart, as predicted by Hypothesis 2? The answer overall is yes: chief judges completed, on average, $76.9 \%$ of their terms. The aggregate number, however, conceals a change over time. Nearly all of the Period 2 chiefs (forty-six out of fifty-one) fulfilled at least half of their terms, and the majority (thirtyeight) served more than $75 \%$ of their terms. By contrast, less than two-thirds of Period 3 chiefs (twenty-six out of forty-one) stayed for at least half of their terms, and only a minority (sixteen) stayed for at least $75 \%$ of their terms. The disparity between the two periods is particularly surprising in light of the seven-year term limit imposed in Period 3. That is, Period 3 judges were limited to a shorter term in absolute years, on average, than Period 2 judges. Nevertheless, Period 3 chief judges have been less likely to complete most of their terms. Thus, Hypothesis 2 finds support for judges who became chief during the 1958-1982 period, but not for judges who became chief within the last twenty-five years.

Most chief judges step down voluntarily. The strategic departure model predicts that they leave early because a judge from the same party will take over as chief. Or, stated differently, they will not step down early if a judge from the opposing party would replace them (Hypothesis 3). As reflected in Table 4, more chief judges departed early when the successor was from the same party than when the successor was from the opposing party. But the difference is not statistically significant: the actual numbers are consistent with the numbers we would expect if party was irrelevant to the chief judge's departure decision.

Table 4. Departing Chief Judge's and Successor's Party: Voluntary Departures

\begin{tabular}{llllll}
\hline & \multicolumn{2}{c}{ Same Party } & \multicolumn{2}{l}{ Opposing Party } & Total \\
\cline { 2 - 5 } Period 1 & 11 & $57.9 \%$ & 8 & $42.1 \%$ & 19 \\
Period 2 & 19 & $52.8 \%$ & 17 & $47.2 \%$ & 36 \\
Period 3 & 19 & $57.6 \%$ & 14 & $42.4 \%$ & 33 \\
ALL & 49 & $55.7 \%$ & 39 & $44.3 \%$ & 88 \\
\hline
\end{tabular}

The chi-square test statistic reveals that, for each period, the party of the departing chief's appointing President is independent of the party of the successor's appointing President. For all periods combined, $\mathrm{X}^{2}=0.98, \mathrm{df}=1, \mathrm{~N} . \mathrm{S}$.

The strategic departure model further predicts that a departing chief judge will be more sensitive to the ideology of her successor when 
the chief is part of the court's minority. Thus, we examined the circuits separately to evaluate the relationship between the party of the chief judge's appointing President and that of her colleagues' appointing Presidents (see Figure 1). ${ }^{167}$ The solid line in each graph is the party of the chief judge. The line is at the top of the graph when the chief judge is a Democratic appointee and at the bottom when the chief is a Republican appointee. The broken line reflects the percentage of the circuit that was appointed by a Democrat; the higher the line, the higher the percentage.

If party control does not affect a chief judge's tenure, we would expect the party of the chief generally to be in line with the circuit. The chief, after all, is drawn from the circuit's membership. Thus, a chief is more likely to be a member of the majority party than the minority party. Given the role of seniority, we should see a slight lag in this relationship after party control shifts. Instead, we observed long periods of minority-party chief judges in the Second, Fourth, Fifth, and Seventh Circuits. And the Third and D.C. Circuits show an effect even though one party dominated each court for long periods. In contrast, the First, Eighth, Tenth, and Eleventh Circuits appear to shift the party of the chief consistently with changes in the composition of the court. Thus, Hypothesis 4 appears an apt account of some circuits but not others.

167. We also examined the relationship when using JCS scores and found a similar trend. Because scores are not available for the entire time, we chose to use party for the purpose of these figures. 
Figure 1. Comparison of Chief Judge's Ideological Position to Circuit's Ideological Position Based on Party of Appointing President, 1948-2006
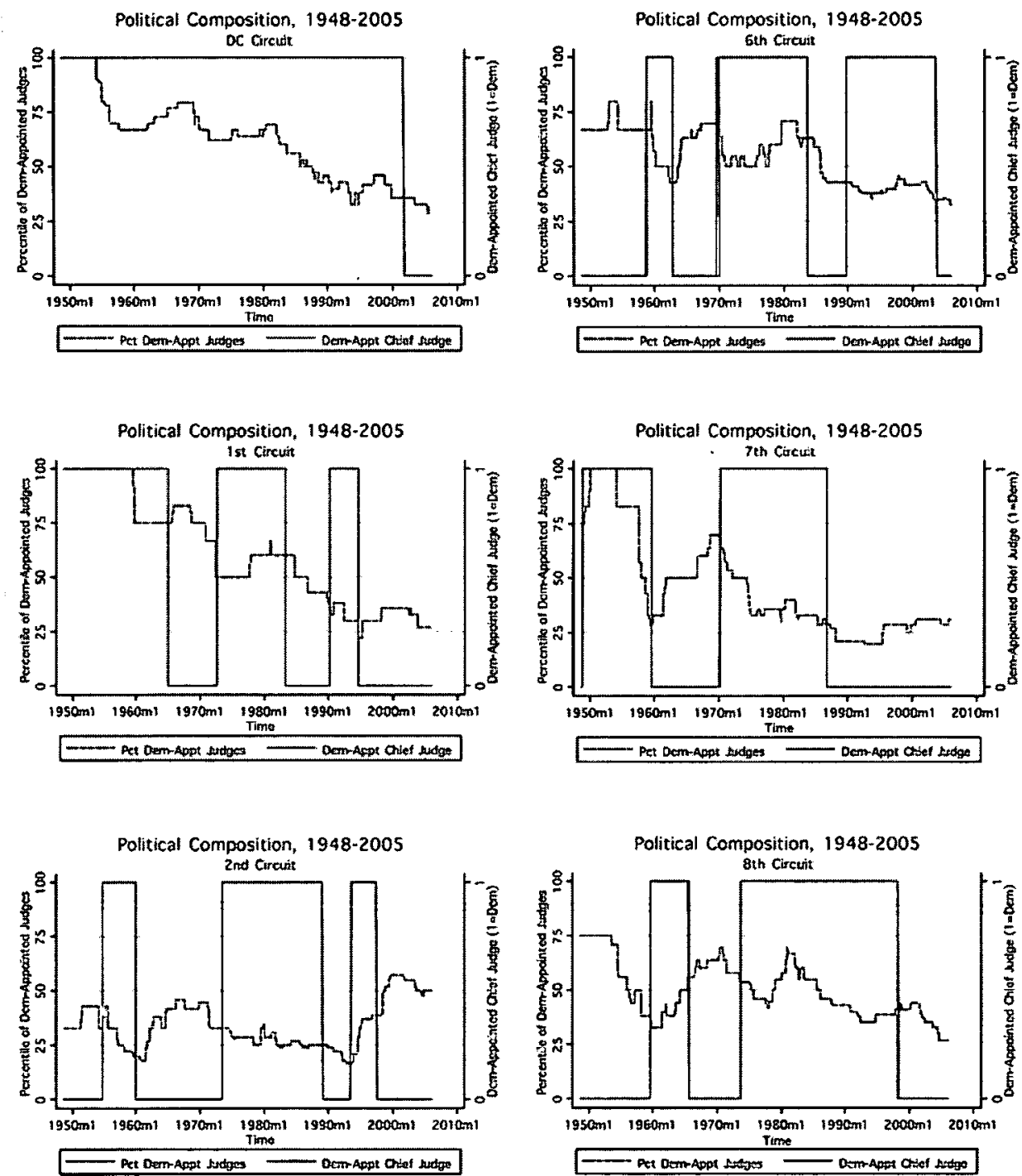

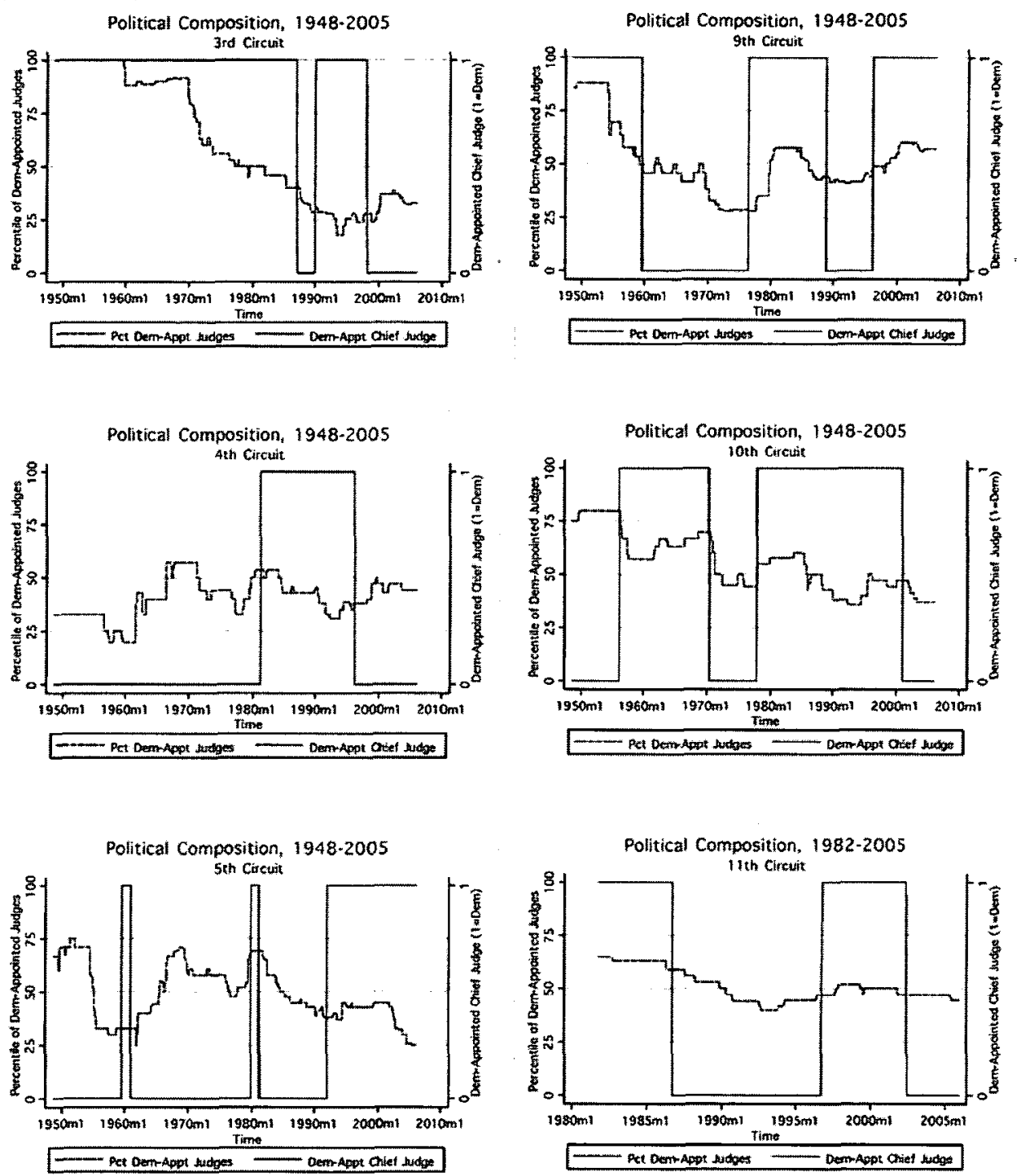
We also used multivariate models to test for an attitudinal effect by controlling for other variables that may influence the decision to step down early, including age, gender, race, and pension qualification. We examined the departure decision from three unique perspectives: (1) a survival model that examined the likelihood that a chief judge would "survive" (i.e., continue in office) each month; (2) a linear regression model that considered the percentage of the term that was completed; and (3) a probit model that took as its dependent variable the simple, binary choice to complete the term or not. ${ }^{168}$ In each model, we measured the tenure decision in a distinct way to increase the likelihood of discovering an attitudinal explanation for chief judge tenure if one exists.

We found little support for an attitudinal theory of chief judge tenure (we report the results for all three models in the Appendix). ${ }^{169}$ The two attitudinal explanatory variables are the party of the chief as compared to the party of her replacement (Hypothesis 3 ) and the party of the chief as compared to the party of the circuit majority (Hypothesis 4). ${ }^{170}$ Neither variable is statistically significant in the survival or linear regression models. Stated differently, the probability that a chief judge will continue as chief in a given month does not depend on whether the likely successor in that month is from the same party or whether the circuit majority is from the same party (survival model). And the attitudinal variables do not impact the percentage of the term completed by the chief judge (linear model). Only the probit model produces a statistically significant result: the probability that a chief judge steps down early increases when the successor is of the same party. The relative contribution of the variable, however, is small. ${ }^{171}$ Given how few chief judges complete a full term, this is not surprising.

168. For a discussion of survival models (also known as hazard or duration models), see Janet M. Box-Steffensmeier \& Bradford S. Jones, Time is of the Essence: Event History Models in Political Science, 41 AM. J. POL. SCI. 1414, 1418-21 (1997). See also Zorn \& Van Winkle, supra note 65 , at 160 (employing hazard models to identify factors that influence the departure of Justices from the U.S. Supreme Court). For a discussion of linear regression models, see JOHN FoX, APPLIEd REgRESSION ANALYSIS, LINEAR MODELS, AND RELATED METHODS 15-23, 85-94 (1997). For a discussion of probit models, see JOHN H. ALDRICH \& FORREST D. NELSON, LINEAR PROBABILITY, LOGIT, AND PROBIT MODELS 30-83 (1984).

169. Several of the controls-gender, months as chief judge, and pension qualification-were statistically significant in most of the model estimations.

170. Party is based on the party of the President who appointed the judge to the circuit court.

171. A chief judge who steps down when the successor is of the same party is $17 \%$ less likely to have completed her term. The probability of completing a term, however, is only $12 \%$. 
Our findings do not mean that chief judges ignore political concerns when making tenure decisions. That is, the failure to reject our null hypothesis (i.e., no attitudinal effect) decidedly is not the same as accepting the null. Nonetheless, a closer look at the data suggests that there is more to the story than attitudinal theory.

\section{B. Circuit Splits}

Circuits vary. Tenure on some circuits appears sensitive to political variables while tenure on other circuits appears sensitive to caseload. The lack of a uniform account for chief judge tenure for all circuits highlights the likely relevance of circuit-specific characteristics such as geography, docket, and history.

We observed a significant variation across circuits in chief judge tenure itself. In several circuits, nearly every judge completed all or almost all of the term. The First Circuit, for example, is the smallest court in terms of caseload and number of judgeships. And the First has grown very slowly over the last fifty years. While the caseload of all circuits increased more than seventeen-fold over that time, the First Circuit saw only a ten-fold increase. We might expect, therefore, that the administrative demands on the head of the First Circuit would be relatively modest compared to those of his colleagues leading other courts. Indeed, most of the eight men who served as chief did so for longer than their peers on other circuits. The two exceptions are Breyer, who left after four years to join the Supreme Court, and Woodbury, who stepped down in 1964 after five and a half years. Woodbury's departure may have been precipitated by workload. The First Circuit saw the largest single-year growth in its caseload in the year immediately preceding his departure. ${ }^{172}$

This cross-circuit variation reveals a challenge to studies of the U.S. Courts of Appeals: it is not a single institution, but rather a collection of separate institutions with common dominant features (such as life tenure and three-judge panel) but salient circuit-specific characteristics. Some of these characteristics may be compared readily across circuits (such as ideological composition), and some may not (such as behavioral norms including civility to colleagues). Moreover, those that may be compared readily may not operate in the same way

172. The docket increased $30 \%$ from 143 to 204 cases for the three active judges on the First Circuit. This was the largest single-year increase that this Circuit had ever experienced. Interestingly, the next largest-28\% in 1971-was soon followed by Woodbury's successor's departure from the position. We see a similar phenomenon on the Third Circuit where Judge William Hastie served as chief for only twenty-five months, departing shortly after the largest increase in circuit history: $36 \%$ in a single year. 
in every circuit, limiting the ability to control them in a dataset that includes all circuits.

\section{Managerial Judging Effects}

What accounts for the increase in early departures from Period 2 to Period 3? As we depicted in Figure 2, the movement is not merely between the two statutorily significant periods; it exists from decade to decade. Chief judges are serving fewer and fewer years in office and also completing a smaller and smaller percentage of their terms.

Figure 2. Chief Judge Tenure by Decade

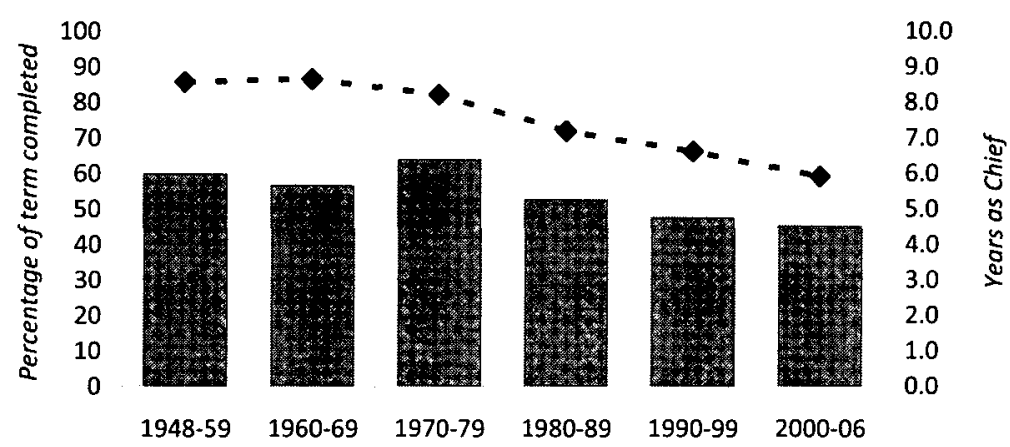

Average number of years as Chief Judge

- - Average percentage of term completed

While the tenure of chief judges is shrinking, the workload of a chief judge has expanded dramatically during the last fifty years. Figure 3 depicts the workload of circuits measured by both the absolute number of annual filings and by annual filings per judgeship. The overall caseload and caseload per judgeship has grown geometrically during this period. The number of judgeships has tripled over the last thirty years, but it has not kept pace with the number of appeals. 
Figure 3. Chief Judge Workload by Decade

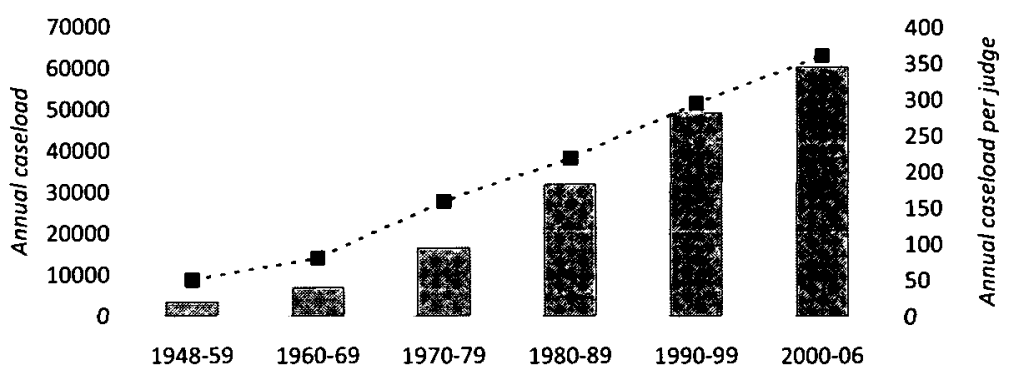

Average annual circuit caseload

- - Average annual caseload per authorized circuit

While the expansion of the federal bench eases the burden on individual circuit judges, it actually increases the burden on chief judges, who manage cases and people. In addition, every circuit is more frequently calling on senior judges, visiting judges, and designated district judges to fill out three-judge panels to the extent that three-quarters of all panels include at least one non-active or noncircuit judge. And chief judges are responsible for inviting and overseeing visitors and senior judges.

The chief judgeship has changed from executive chief to ministerial chief: In the 1960s and most of the 1970s, the number of circuit judges remained below one hundred and case filings below 20,000 . But in the early 1980 s, the number of per judge filings had topped 200 and the number of filings exceeded 30,000. Comparing Figures 2 and 3 , the negative correlation between workload and chief judge tenure is clear. ${ }^{173}$

Workload, then, may limit the ability of the chief judge to achieve her policy goals while in office. Thus, the attitudinal account of chief judge tenure, standing alone, is insufficient. Or at least the account as set forth here is insufficient. Perhaps modern chief judges who are policy-oriented realize that they are more likely to affect policy outcomes as regular judges-where they can focus on casesthan as chiefs-where they are too overwhelmed by the workload to be attentive to policy goals. 


\section{CONCLUSION}

Grutter v. Bollinger garnered a great deal of attention because it involved a politically and socially salient substantive issue: affirmative action. It also offered insight into a distinct but equally relevant one: the incentives of federal appellate judges. Political scientists, legal scholars, and judges have debated the relative role of the law and politics in the decisions of appellate judges. We think the issue is more complex. The real world context of those decisions includes the caseload of the judges and the growth of law. And our results show that workload, at least for chief judges, matters. Perhaps the chief judge is uniquely positioned; the chief has the most potential policymaking power of any judge on a particular court (circuit or Supreme), but also is most likely to be affected by workload. We can know only by including workload as a factor in our studies of judicial politics.

We also found that the federal courts of appeals are not a monolithic institution, but are instead twelve distinct courts. They do share numerous features, many of which are relevant to the decisions of individual judges, but they are heterogeneous. Empirical and normative studies of circuit courts must take into account their unique historical, geographic, and legal characteristics.

Twenty-five years ago, Congress set a seven-year term limit out of concern that chief judges stay too long in the post. Ironically, the opposite problem has emerged: chiefs are leaving too early. The term limit itself may bear part of the blame-it may have diluted the honor. Fixed finite tenure may make any institutional control by the chief judge weaker. It also increases the number of judges who serve as chief, meaning the position offers less prestige than it did previously. ${ }^{174}$ We are at risk that judges will not agree to serve as chief or, if they do serve, they will not stay on long enough to gain the experience and knowledge that would make them more effective and efficient managers of the courts. Chief judges wield power. We should want them to do so wisely. 


\section{APPENDIX}

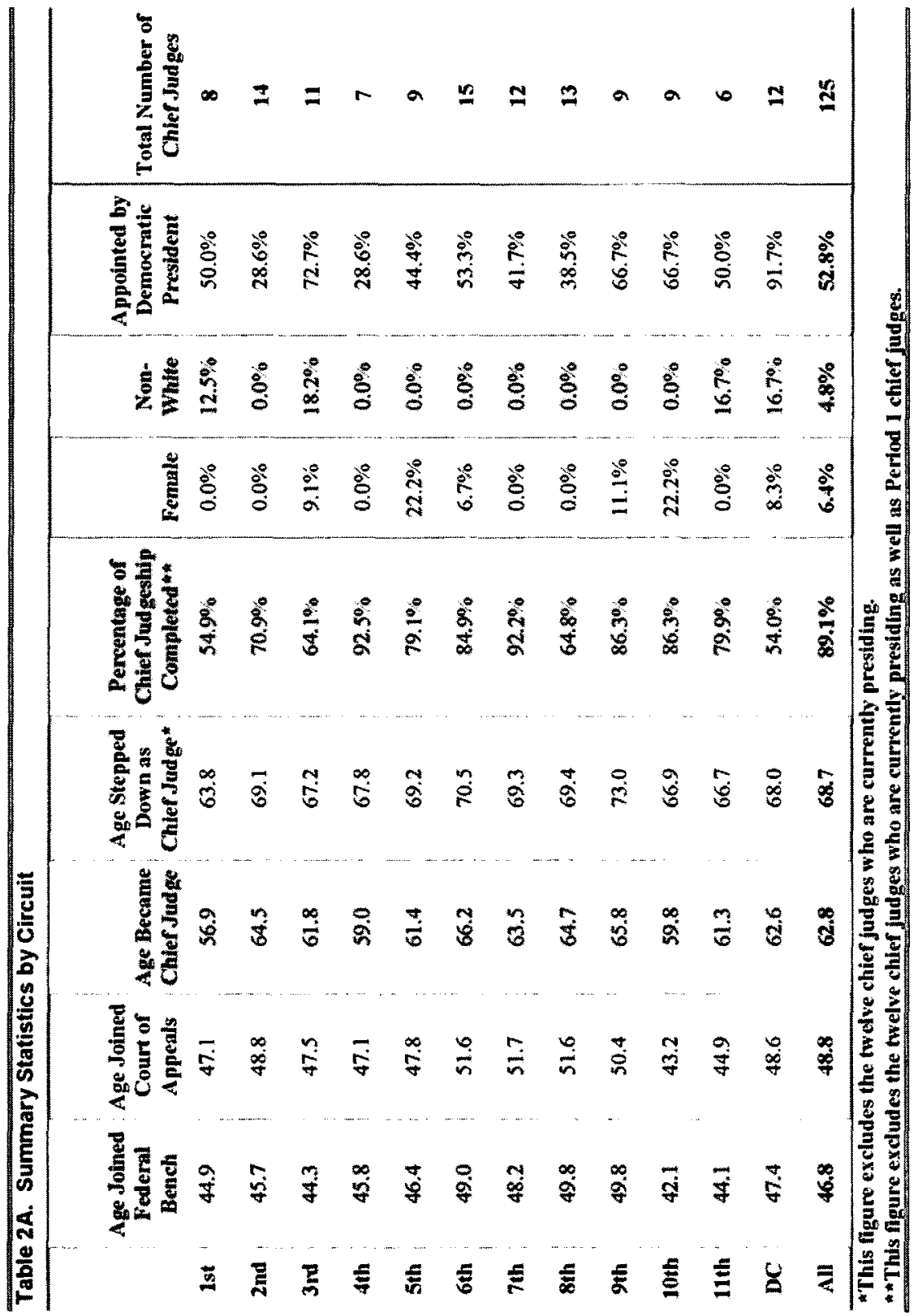




\section{Table 5. Multivariate Models of Chief Judge Tenure}

We are trying to explain the decision to depart from the chief judge position. We hypothesize that the decision is affected by numerous variables, the value of which depends on the particular chief judge. Those judge-specific explanatory variables (independent variables) are gender, race, age, ideology of the chief as compared to ideology of the replacement, and ideology of the chief as compared to ideology of the circuit. (We report here the numbers for the appointing President's party as the measure for ideology, but we also ran JCS scores as the measure and still did not find a statistically significant relationship between ideology and departure.)

For each model below, the dependent variable is the chief judge's tenure. Table 5.1 presents the survival model (also known as a duration or hazard model), estimated using nonparametric maximum likelihood ("NPMLE"), in which the dependent variable is whether the chief judge continued to serve at a particular point in time or if, instead, the chief stepped down. Table 5.2 presents the linear regression model, estimated using ordinary least squares ("OLS"), in which the dependent variable is the percentage of the term completed. Table 5.3 presents a probit model, estimated using maximum likelihood ("MLE"), in which the dependent variable is the probability of departing early. We present results from three versions of each model: version 1 has neither period nor circuit controls, version 2 controls for period, and version 3 controls for period and for circuit.

A few caveats are necessary. First, each model has a unique dependent variable. We can't then compare goodness of model fit across models. Second, only the hazard model considers the changing values of time-varying dependent variables. For monotonic variables such as months as chief judge, interpretation of the OLS and MLE results is fairly straightforward. However, for non-monotonic variables such as circuit composition and successor identity, neither the linear regression nor probit models take into account the value of the variable in prior periods while the chief judge remained in office. 
Table 5.1. Survival Model of Chief Judge Tenure

\begin{tabular}{|c|c|c|c|}
\hline & 1 & 2 & 3 \\
\hline Female & $\begin{array}{c}0.0101 \\
(0.0066)\end{array}$ & $\begin{array}{c}0.0091 \\
(0.0065)\end{array}$ & $\begin{array}{l}0.0130^{*} \\
(0.0068)\end{array}$ \\
\hline White & $\begin{array}{c}0.0062 \\
(0.0055)\end{array}$ & $\begin{array}{c}0.0022 \\
(0.0047)\end{array}$ & $\begin{array}{c}0.0024 \\
(0.0053)\end{array}$ \\
\hline Months as Chief Judge & $\begin{array}{c}0.0001 \\
(0.0000)\end{array}$ & $\begin{array}{c}0.00003 \\
(0.00002)\end{array}$ & $\begin{array}{l}0.0001^{*} \\
(0.0000)\end{array}$ \\
\hline $\begin{array}{l}\text { Chief Judge Appointed } \\
\text { by Democratic President }\end{array}$ & $\begin{array}{l}-0.0002 \\
(0.0020)\end{array}$ & $\begin{array}{l}-0.0017 \\
(0.0018)\end{array}$ & $\begin{array}{l}-0.0017 \\
(0.0016)\end{array}$ \\
\hline $\begin{array}{l}\text { Circuit Majority Appointed } \\
\text { by Democratic President }\end{array}$ & $\begin{array}{l}-0.0018 \\
(0.0018)\end{array}$ & $\begin{array}{c}0.0004 \\
(0.0020)\end{array}$ & $\begin{array}{c}0.0005 \\
(0.0020)\end{array}$ \\
\hline $\begin{array}{l}\text { Chief Judge and Circuit Majority } \\
\text { of Same Party }\end{array}$ & $\begin{array}{l}-0.0024 \\
(0.0022)\end{array}$ & $\begin{array}{l}-0.0020 \\
(0.0020)\end{array}$ & $\begin{array}{l}-0.0012 \\
(0.0018)\end{array}$ \\
\hline $\begin{array}{l}\text { Chief Judge and (Anticipated) } \\
\text { Successor of Same Party }\end{array}$ & $\begin{array}{c}0.0036 \\
(0.0020)\end{array}$ & $\begin{array}{c}0.0031 \\
(0.0018)\end{array}$ & $\begin{array}{c}0.0029 \\
(0.0018)\end{array}$ \\
\hline Qualified for Pension & $\begin{array}{l}0.0241^{*} \\
(0.0033)\end{array}$ & $\begin{array}{l}0.0292^{*} \\
(0.0036)\end{array}$ & $\begin{array}{l}0.0282^{*} \\
(0.0037)\end{array}$ \\
\hline $\begin{array}{l}\text { Control for Period Regarding } \\
\text { Chief Judge Service }\end{array}$ & $\mathrm{N}$ & $\mathrm{Y}$ & $\mathrm{Y}$ \\
\hline Control for Circuit & $\mathrm{N}$ & $\mathrm{N}$ & $\mathrm{Y}$ \\
\hline \multicolumn{4}{|c|}{$\begin{array}{l}\mathrm{N}=8373 \text {. The dependent variable is whether the chief stepped down from leadership in a given } \\
\text { month. The survival model is estimated using probit regression, controlling for correlation } \\
\text { across months for individual chief judges. The coefficients report mean marginal effects, with } \\
\text { interpretation similar to ordinary least squares ("OLS"). The value in parentheses below each } \\
\text { coefficient is the standard error. An asterisk marks estimates that are statistically significant } \\
\text { at or below the } .05 \text { level. }\end{array}$} \\
\hline
\end{tabular}


Table 5.2. Ordinary Least Squares Model of Chief Judge Tenure

\begin{tabular}{|c|c|c|c|}
\hline & 1 & 2 & 3 \\
\hline Female & $\begin{array}{l}17.0342^{\star} \\
(7.1705)\end{array}$ & $\begin{array}{l}20.2061^{*} \\
(6.6813)\end{array}$ & $\begin{array}{l}21.2403^{\star} \\
(9.4251)\end{array}$ \\
\hline White & $\begin{array}{l}-10.1282 \\
(12.0058)\end{array}$ & $\begin{array}{c}-3.7970 \\
(12.8973)\end{array}$ & $\begin{array}{c}0.5888 \\
(11.1553)\end{array}$ \\
\hline Months as Chief Judge & $\begin{array}{l}0.2209^{\star} \\
(0.0557)\end{array}$ & $\begin{array}{l}0.2209^{\star} \\
(0.0535)\end{array}$ & $\begin{array}{l}0.2221^{*} \\
(0.0620)\end{array}$ \\
\hline $\begin{array}{l}\text { Chief Judge Appointed } \\
\text { by Democratic President }\end{array}$ & $\begin{array}{c}4.0990 \\
(5.07676)\end{array}$ & $\begin{array}{c}4.9580 \\
(4.8210)\end{array}$ & $\begin{array}{l}2.2711 \\
(5.070)\end{array}$ \\
\hline $\begin{array}{l}\text { Circuit Majority Appointed } \\
\text { by Democratic President }\end{array}$ & $\begin{array}{l}10.1092 \\
(5.1717)\end{array}$ & $\begin{array}{l}-0.2156 \\
(5.2463)\end{array}$ & $\begin{array}{c}2.2511 \\
(6.1552)\end{array}$ \\
\hline $\begin{array}{l}\text { Chief Judge and Circuit Majority } \\
\text { of Same Party }\end{array}$ & $\begin{array}{l}-4.3904 \\
(5.4585)\end{array}$ & $\begin{array}{c}-3.9230 \\
(5.2025)\end{array}$ & $\begin{array}{l}-3.5418 \\
(5.8016)\end{array}$ \\
\hline $\begin{array}{l}\text { Chief Judge and (Anticipated) } \\
\text { Successor of Same Party }\end{array}$ & $\begin{array}{l}-2.5233 \\
(5.8623)\end{array}$ & $\begin{array}{l}-1.2644 \\
(5.7075)\end{array}$ & $\begin{array}{l}-2.2154 \\
(6.4023)\end{array}$ \\
\hline Qualified for Pension & $\begin{array}{c}6.8391 \\
(9.0538)\end{array}$ & $\begin{array}{c}7.7411 \\
(8.9815)\end{array}$ & $\begin{array}{c}7.7927 \\
(9.4658)\end{array}$ \\
\hline $\begin{array}{l}\text { Control for Period Regarding } \\
\text { Chief Judge Service }\end{array}$ & $\mathrm{N}$ & $\mathrm{Y}$ & $\mathrm{Y}$ \\
\hline Control for Circuit & $\mathbf{N}$ & $\mathrm{N}$ & $\mathbf{Y}$ \\
\hline \multicolumn{4}{|c|}{$\begin{array}{l}\mathrm{N}=98 \text {. The dependent variable is the percentage of the term that the chief served (scale from } \\
0 \text { to } 100 \text { ), and the linear regression model is estimated using OLS. The value in parentheses } \\
\text { below each coefficient is the standard error. An asterisk marks estimates that are } \\
\text { statistically significant at or below the } .05 \text { level. }\end{array}$} \\
\hline
\end{tabular}


Table 5.3. Probit Model of Chief Judge Tenure

1

0.3106

$(0.2362)$

0.1452

$(0.0685)$

$0.0008^{*}$

(0.0004)

$-0.0142$

(0.0562)

.0 .0606

(0.0501)

0.0062

$(0.0569)$

$-0.1726^{*}$

(0.0896)

$-0.2302^{*}$

(0.1340)

$\mathrm{N}$

Control for Period Regarding

Chief Judge Service

Control for Circuit

N
2

3

$0.2635^{*}$

(0.1795)

(0.2059)

0.0780

$(0.1458)$

-0.0003
$(0.0408)$

$0.0008^{*}$

(0.0004)

$(0.0003)$

$-0.0111$

$(0.0367)$

$(0.0384)$

$-0.0016$

(0.0426)

-0.0229
$(0.0347)$

0.0167

(0.0324)

(0.0381)

$-0.1486^{*}$

(0.0842)

(0.0693)

$-0.2133^{*}$

(0.1226)

$-0.1769^{*}$

Y

$\mathrm{Y}$

Y

81

When adding circuit controls, the number of observations drops from 98 to 81 . This occurs because in the 1st, 9th, and 11th Circuits, the chief judges do not vary with respect to the dependent variable.

The dependent variable is whether the chief completed the full term, using a probit model. The coefficients report mean marginal effects, with interpretation similar to OLS. The value in parentheses below each coefficient is the standard error.

An asterisk marks estimates that are statistically significant at or below the .05 level. 


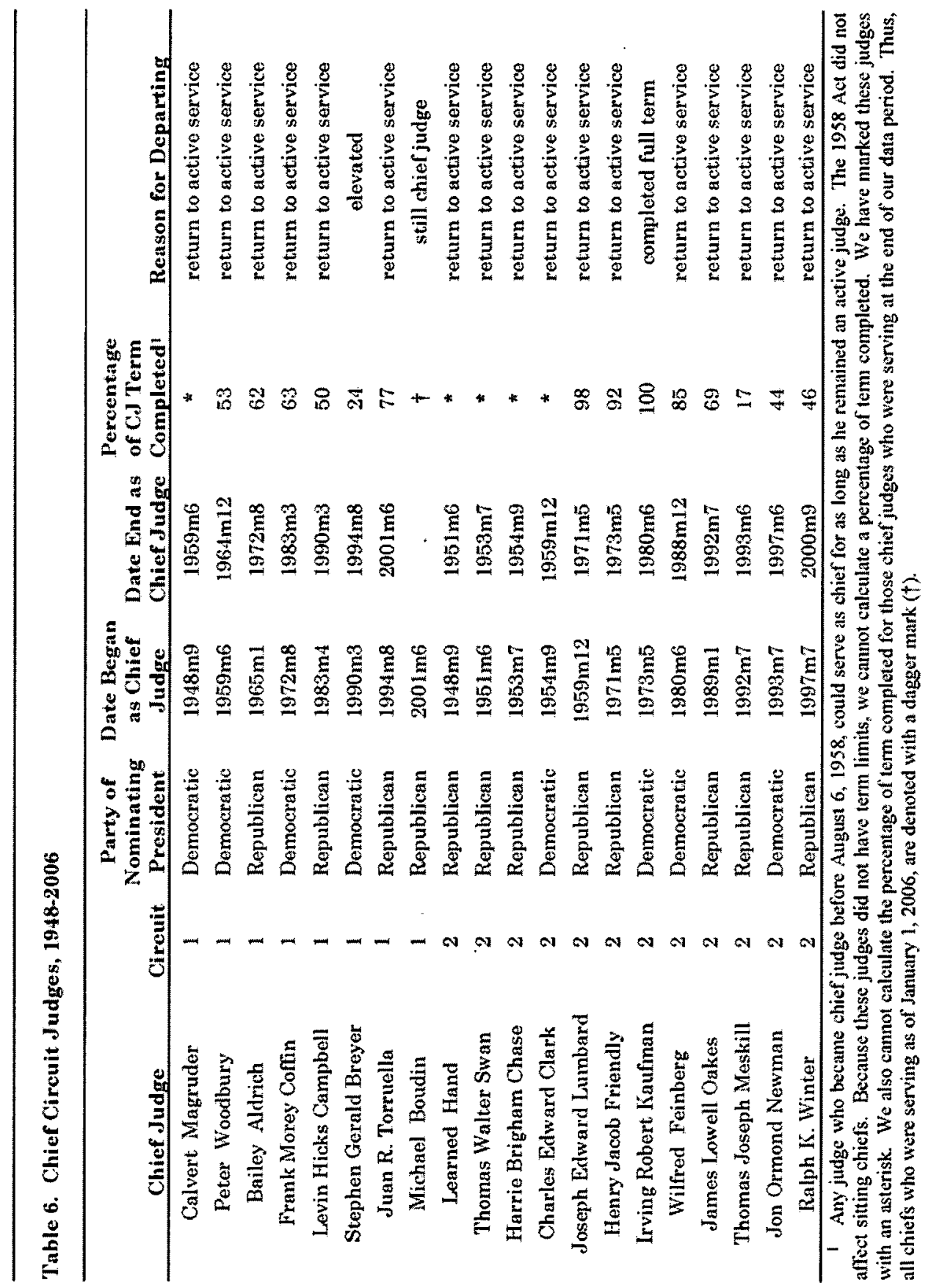




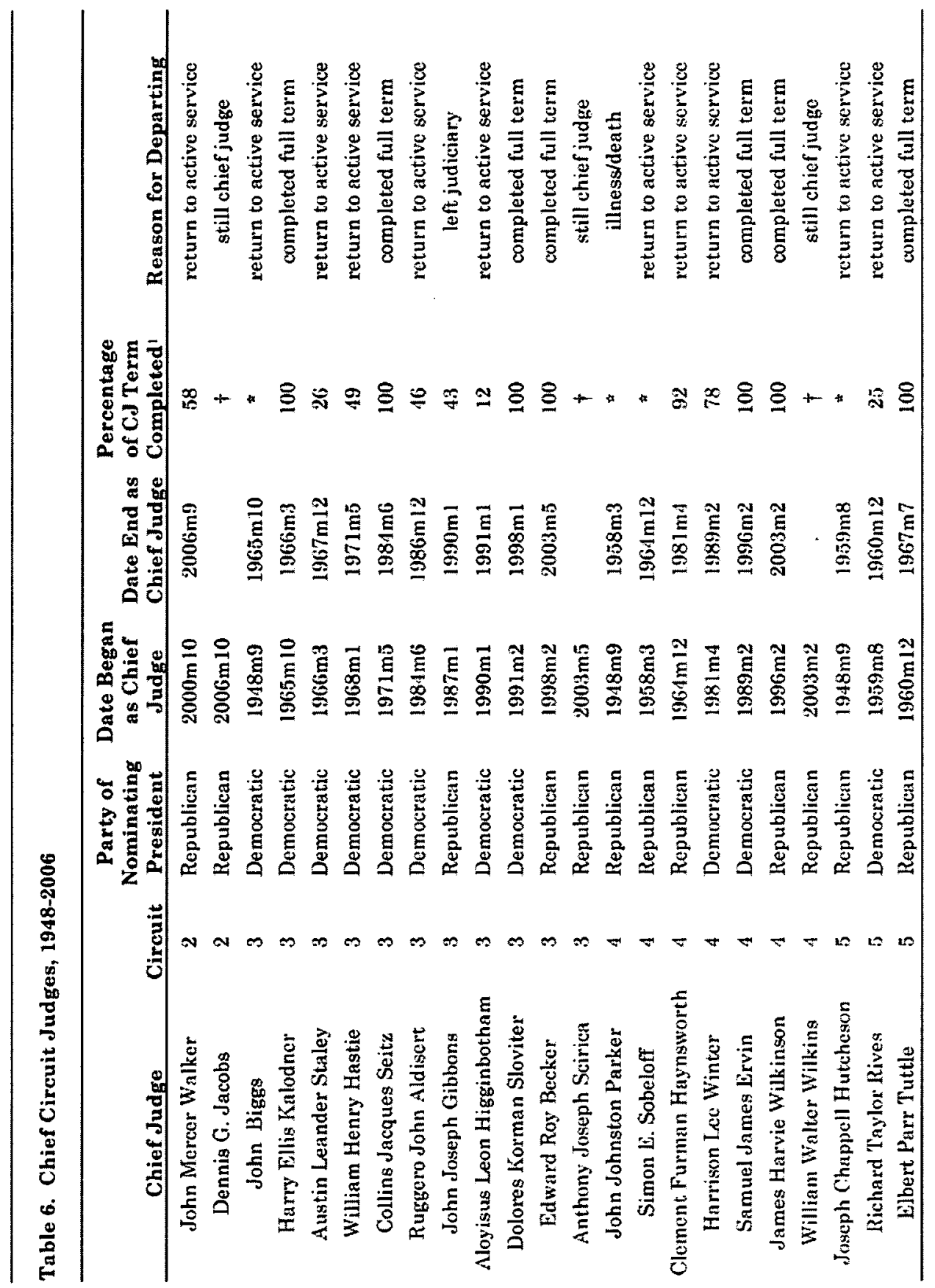




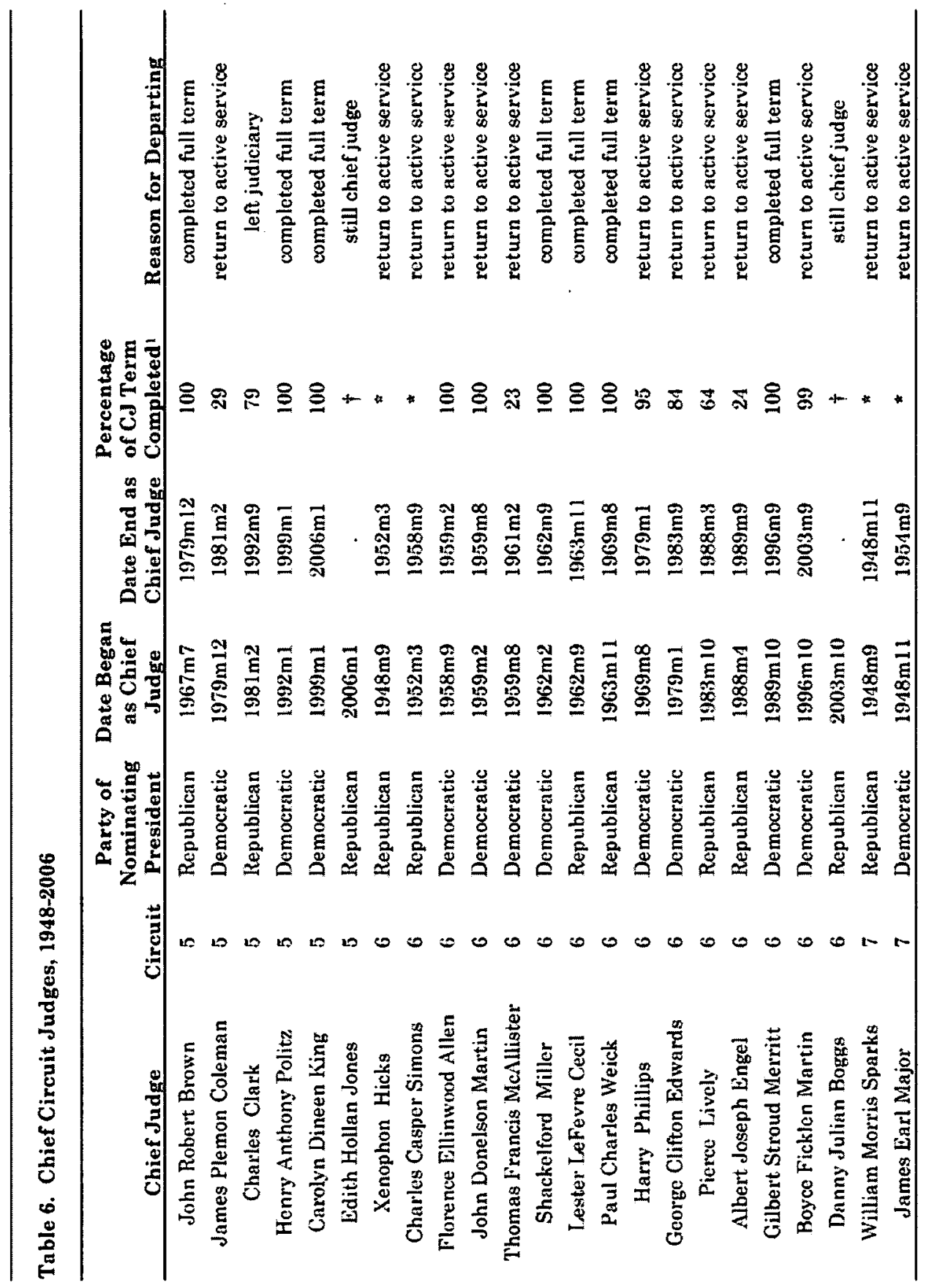




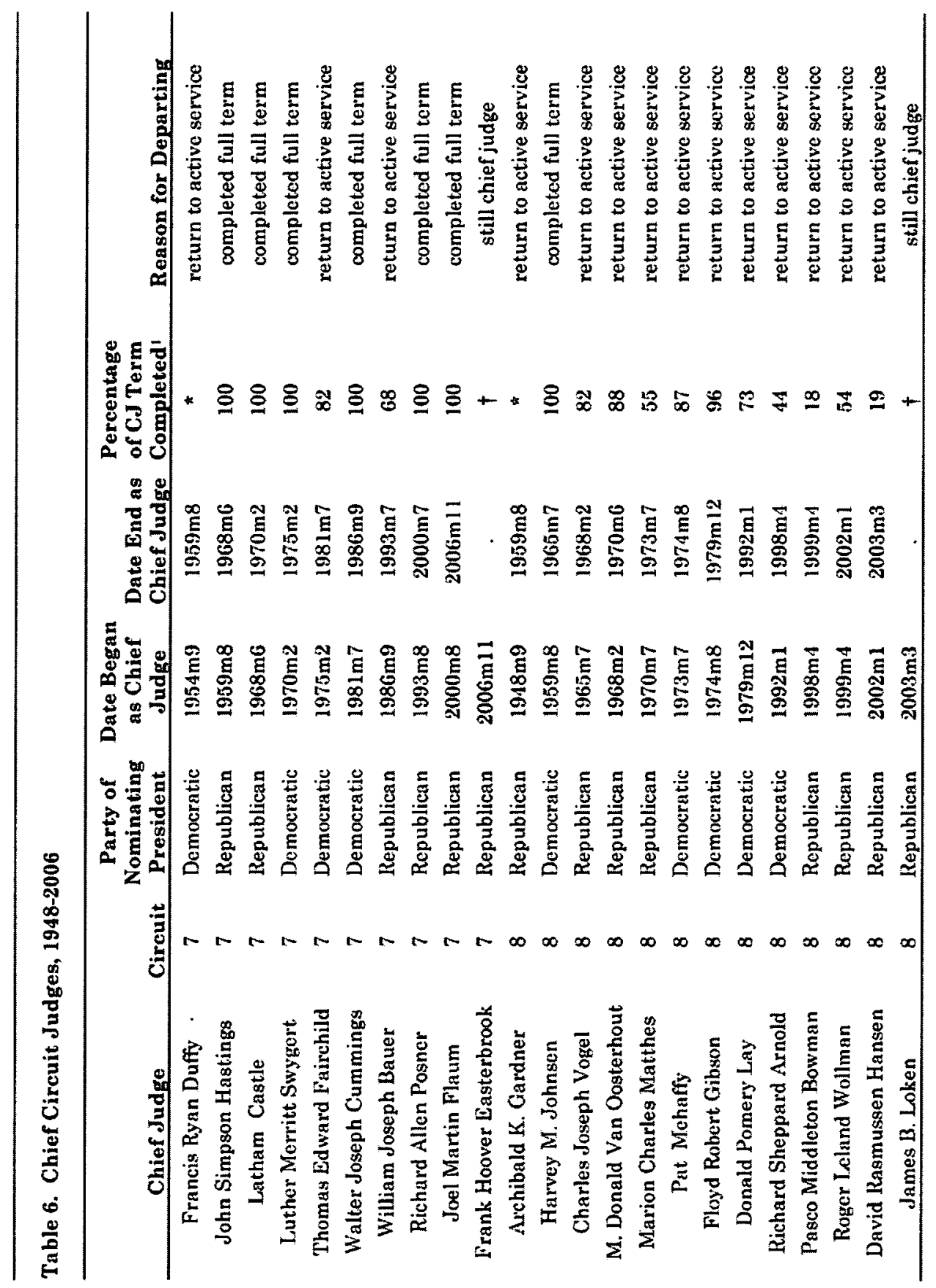




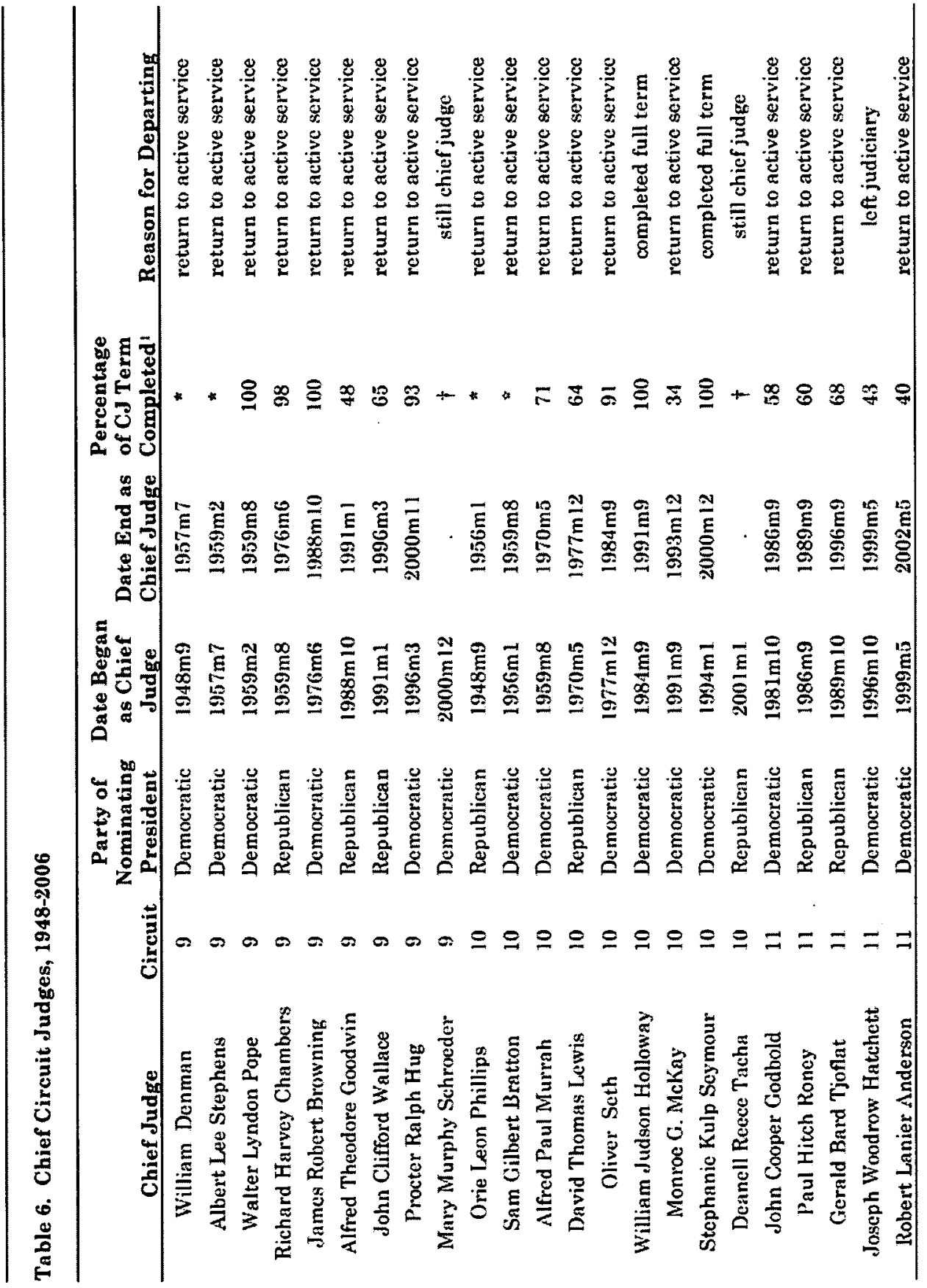




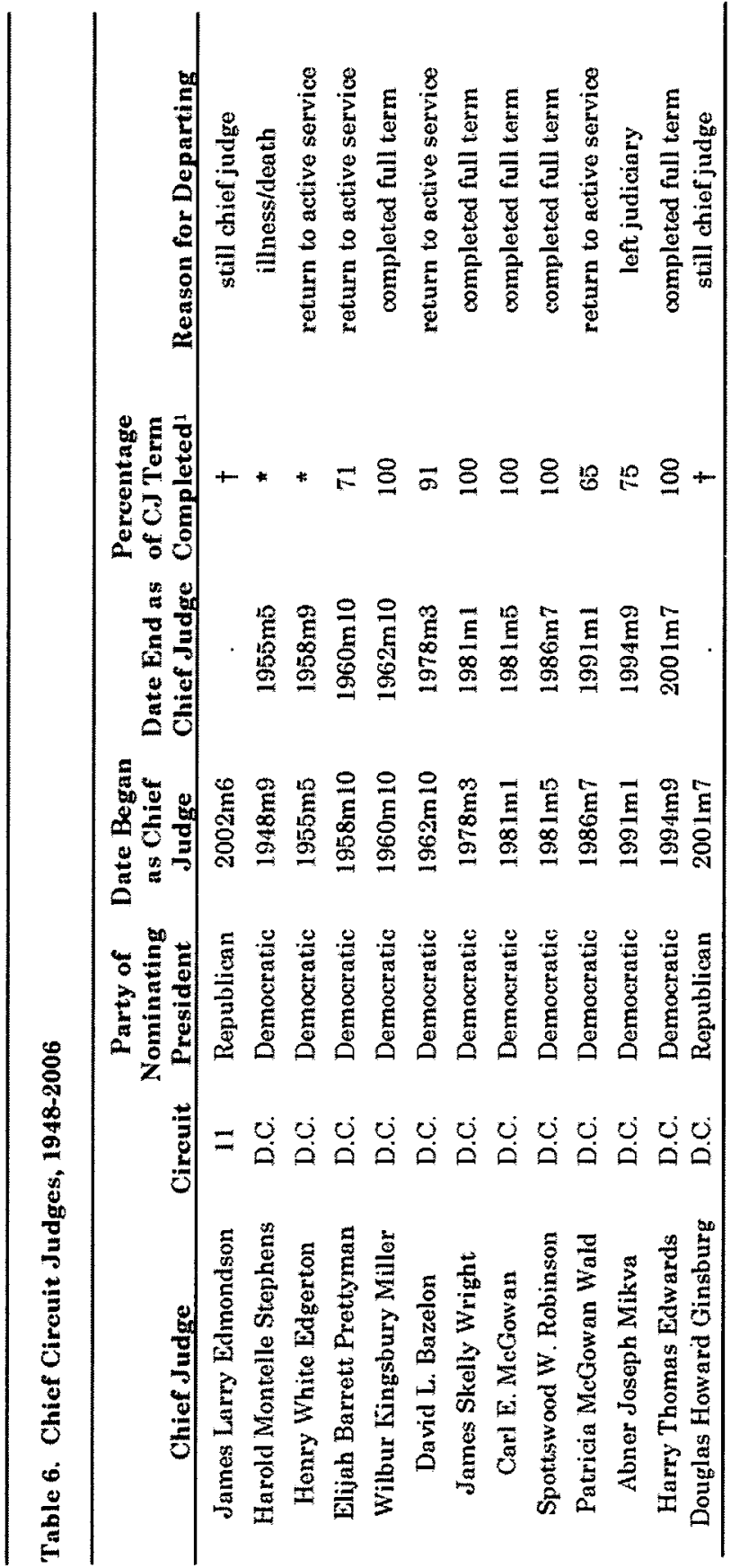


***

HeinOnline -- 61 Vand. L. Rev. 622008 


\section{Constitutional Evidence Law}

Alex Stein

61 Vand. L. Rev. 65 (2008)

This Article identifies the causes and consequences of $a$ puzzling asymmetry in constitutional law. Of the three facets of adjudicative fact-finding-evidence, procedure, and rules of decision-only two are constitutionalized. Constitutional law regulates procedural and decisional rules-not whether the evidence that fact-finders use is adequate. Allocation of the risk of error by procedures and decisional rules-formulated as burdens of proof-is subject to constitutional scrutiny. Allocation of the risk of error by the rules of evidential adequacy, however, is free from that scrutiny. This constitutional asymmetry is puzzling because all riskallocation impacts court decisions and, consequently, whether a person is deprived erroneously of her liberty or property. This Article explains this asymmetry in the informal constitutionalization of evidence-a phenomenon that implicates three dynamics of power and culture. First, state evidence rules generally align with the Supreme Court's agenda for risk-allocation. Second, when those rules do deviate from the Court's agenda to promote local interests, they do not do so overtly. Finally, a state rule's alignment with a federal rule of evidence guarantees its constitutionality. This informal order reflects a series of implicit, but credible understandings between state courts and the Supreme Court. This Article identifies and illustrates these understandings. 
$* * *$

HeinOnline -- 61 Vand. L. Rev. 642008 